\title{
Dil ve söylem pratiklerini haber metinlerinde aramak: Yeni Zelanda terör saldırısı örneği
}

\section{Abdulkadir GÖLCÜ'1 Enes BAL 2 Betül KARADENİZ3}

\begin{abstract}
APA: Gölcü, A.; Bal, E.; Karadeniz, B. (2019). Dil ve söylem pratiklerini haber metinlerinde aramak: Yeni Zelanda terör saldırısı örneği. RumeliDE Dil ve Edebiyat Araştırmaları Dergisi, (17), 220-251. DOI: $10.29000 /$ rumelide.656724
\end{abstract}

\section{Öz}

Terör, insanlar üzerinde korku yaratmak amacıyla gerçekleştirilen ve temelinde şiddet olan sembolik bir eylemdir. İnsanlık tarihinin her döneminde meydana gelen terör eylemlerinin medya üzerindeki yansıması ise medya kuruluşlarının benimsemiş oldukları yayın politikalarına göre farklılık göstermektedir. Bu farklılık, kamuoyunun bilgilendirilme sürecinde terör haberlerinde kullanılan dil ve söylemde ortaya çıkmaktadır. Bu çerçevede terör eylemlerinin haberleştirilmesinde tercih edilen dilin kullanımı ile ortaya çıkan söylemin çözümlenmesi ise gazete yayın politikalarının haberin dili ve söylemine etkisini anlamak açısından önemlidir. Bu çalışmanın amacı, farklı siyasal tercihlere yönelik habercilik yapan medya kuruluşlarının editoryal politikalarının, terör eylemlerinin haberleştirilme sürecinde haber dili ve söylemine etkisini ortaya koymaktır. Bu bağlamda, 15 Mart 2019'da Yeni Zelanda'da Cuma namazı sırasında iki camiye düzenlenen silahlı terör saldırısı ile ilgili yazılı basında yer alan haberlerin okuyucuya nasıl sunulduğu ve nasıl bir söylem geliştirildiği çalışmanın ana konusunu oluşturmaktadır. Bu doğrultuda, 16 Mart-23 Mart 2019 tarihleri arasında yayın politikaları birbirinden farklı olan Cumhuriyet, Milli Gazete, Orta Doğu, Sözcü, Yeni Akit ve Yeni Şafak olmak üzere toplam altı gazete belirlenmiştir. Seçilen gazetelerin olayla ilgili yaptı̆̆ı tüm baş sayfa haberlerinin başlıkları, içerikleri, görselleri ve gazetelerin olaya ilişkin bakış açıları Teun van Dijk’ın sistematikleştirdiği söylem analizi yöntemi ile analiz edilmiştir. Araştırma sonucunda aynı olayın, birbirinden farklı bakış açılarına sahip gazetelerde, farklı söylem kalıpları ile haberleştirildiği, olaya ilişkin basının vermiş olduğu önemin kısa zamanda azaldığı tespit edilmiştir.

Anahtar Kelimeler: Terör, söylem, haber söylemi, haber dili, gazete yayın politikaları.

\section{Looking for the language and discourse practices in news texts: New Zealand terror attacks case}

\begin{abstract}
Terrorism, fundamentally, is a symbolic action that aims to incite fear in people. The terrorist actions that have occurred throughout the history of humanity has been reflected in media in various ways based on the editorial policies that are adopted by media organizations. The diversity in media transpires in the process of informing the society through the terrorism-related news, in terms of the

1 Doç. Dr., Selçuk Üniversitesi, İletişim Fakültesi, Gazetecilik Bölümü (Konya, Türkiye), kadirgolcu@yahoo.com, ORCID ID: 0000-0001-7320-6745 [Makale kaylt tarihi: 06.11.2019-kabul tarihi: 20.12.2019; DOI: 10.2900o/rumelide.656724] Dr. Öğr. Üyesi, Necmettin Erbakan Üniversitesi, Sosyal ve Beşeri Blimler Fakültesi, Halkla İlişkiler ve Reklamcılık Bölümü (Konya, Türkiye), enesbal@hotmail.com, ORCID ID: 0000-0002-6426-9426

YL Öğrencisi, Selçuk Üniversitesi, Sosyal Bilimler Enstitüsü, Gazetecilik ABD (Konya, Türkiye), betulkaradeniz@hotmail.com, ORCID ID: oooo-0002-1066-1684
\end{abstract}




\begin{abstract}
language and discourse. In this context, the analysis of the discourse that arises with use of preferred language in the reporting of terrorist acts is important for understanding the effect of newspaper publishing policies on the language and discourse of the news. The aim of this study is to reveal the effect of editorial policies of media organizations reporting on different political preferences on news language and discourse in the process of reporting terrorist acts. In this respect, how the news that took place in the print press about the armed terrorist attacks carried out at two mosques during Cum'a prayer in New Zealand on 15 March 2019 were presented to the readers and how the discourses were developed form the topic of the current study. Accordingly, the 6 newspapers, whose editorial policies differed between 16th and 23rd March 2019, were chosen: Yeni Akit, Orta Doğu, Yeni Şafak, Milli Gazete, Sözcü and Cumhuriyet. The front-page news about the incident that took place in the selected newspapers were analyzed in terms of their headlines, contents and the point of view depending on van Dijk's discourse analysis method. As a result of the study, it's found that the same incident was reported in various discourse patterns in newspapers whose point of views were different than each other's. As a result of the research, it was found that the same event was communicated with different discourse patterns in the newspapers with different perspectives, and the importance of the press about the event decreased in a short time.
\end{abstract}

Keywords: Terror, discourse, news discourse, news language, newspaper publication policies.

\title{
Giriş
}

Terör kavramı, genel olarak politik bir amaca ulaşmak amacıyla devlete, halka ve bireylere yönelik sistemli şiddet eylemlerine karşllı gelmektedir. Terörün sistematik haline terörizm, onu gerçekleştirene de terörist denmektedir. Terörizmin tek bir ideolojisi yoktur, bunun için de teröristler her türlü ideolojiden ve dinden olabilmektedir (Aydın, 2013: 452). Tarihsel süreçte bakıldığında terör eylemlerinin farklı dönemlerde ve sosyal yapılarda değişkenlik göstermişse de düşünce yapısının ve işleyişinin genelde aynı kaldığı görülmektedir (Özüyılmaz ve Demir, 2011:108). Dolayısıyla terör kavramının net bir tanımı yapılamamakla birlikte özlüce, bir amaca ulaşmak için daha önceden belirlenmiş masum hedeflere yöneltilen, temelinde şiddet olan ve belli kesimler üzerinde korku ve panik uyandırmak amacıyla gerçekleştirilen sembolik bir eylemdir. Terörizm ise katılımcılarıyla birlikte önceden planlayarak gerçekleştirdiği sıra dışı şiddet eylemleri ile kendi siyasi, dinsel ve ideolojik hedeflerine ulaşmayı amaçlayan bir yöntemdir (Şen ve Özuyar, 2015:19). Bu bağlamda terör kavramı uzun süreli dehşet ve korku durumunun stratejik eylem boyutunu ifade ederken, terörizm ise bu durumun ortaya çlkarılmasını amaçlayan stratejik söylemi ifade etmektedir (Çora, 2008:17).

Günümüzde ise terörizm, küreselleşmeye paralel olarak değişim yaşayarak etkinliğini ve yaygınlığını arttıran bir yapıya sahip olmuşstur. Terör eylemlerinin etkinliğinin artmasında en büyük etken, seslerini daha geniş kitlelere duyurabilmek için medyayı etkili bir araç olarak kullanmaları olmuştur. Bir başka ifade ile medya, terörün etkililiğini yerelden uluslararası bir boyuta taşımıştır. Artık terör eylemlerinde temel amaç, gerçekleştirdikleri eylemlerin niteliğinin yanı sıra tüm medya kuruluşlarında varlıklarını gösterebilmek olmuştur. Terör eylemlerinin medyada yer almayı isteme nedeni ise medya aracılığıyla kitlelerin kendisini seyretmesini sağlamak, silahlı eylemler ile propagandasını yapmak, bunun sonucunda devlet/sistem otoritesini sarsmak, devletin/sistemin silahlı güçlerini şiddete yönelterek kargaşa hali oluşturmak, bu eylemler neticeli örgüte üye olanların ve sempatizanların veya sempatizan adaylarının moralini yükseltmek, yoğun eylemler neticesinde sistemi ve onun temsilcisi olan güçleri ylldırmak ve sindirmek, farklı etnik gruptaki çoğunluğun/karşı grubun moralini bozarak tedhiş hali yaratmaktır (Okyar ve Güneş, 2011:141). Bu açıdan ele alındığında, meydana gelen terör saldırıları 
basının üzerinde durduğu önemli konulardan biri olmaktadır. Çünkü terörizm söylemden çıkıp eyleme dönüştüğ̈̈ zaman; can kayıpları, yaralılar, büyük ekonomik kayıplar söz konusu olmakta ve bu da gazetelerin ideolojik yapıları ne olursa olsun haber olarak ilk sırada kendini göstermektedir (Karaduman ve Akbulutgiller, 2018:13). Ancak medya kuruluşlarının her olayda olduğu gibi terör konusunu da işlerken tavır ve tutumları, kullandığı dil ve söylem, olayı nasıl ele aldığı ve okuyucuya ne şekilde aktardığı terör haberlerinde de farklılaşmaktadır (Duruoğlu, 2007:3).

Her medya kuruluşunun kendi yayın politikasına göre şekillenen haberler, haber metinlerinde tercih edilen dil ve söylemler aracıllğıyla gerçekliğin bir yansıması olarak yeniden üretilerek kitlelere aktarılmaktadır. Bu bağlamda, gazete yayın politikalarının etkisi haber diline, söylemine, sunumuna ve içeriğine yansımaktadır. Terör haberlerinde bu durumun yansıması ise medya kurumlarının yönelimlerine göre aynı olayın farklı tanımlamalarla yani farklı dil ve söylem kalıpları ile ifade edilmesidir. Bir medya kuruluşuna göre faşist olanın, diğerine göre vatansever olması, birine göre terörist olanın, diğerine göre gerilla olarak adlandırılması gibi (Arıboğan, 2007:105). Bu açıdan ele alındığında bir olayın nasıl haberleştirildiği, kelimelerin seçimi, halkın olayı farklı şekilde yorumlamasına neden olabilmekte ve aynı olayın farklı tanımlamalarla ifade edilmesi her olayı farklı şekilde açıklamasına neden olmaktadır (Melek ve Toker, 2016:1 83). Nitekim bir medya organının haberlerinde kullandığı dil ve söylem, o medya kuruluşunun genel yayın politikasını net bir şekilde ortaya koymaktadır. Çünkü haber metinlerinde kullanılan dil aracılı̆̆ıyla inşa edilen söylemler ile egemen ideoloji doğallaşmakta ve yeniden tanımlanmaktadır. Bu bağlamda haber metinlerinin içeriğinin analiz edilmesi, yani dil ve söylemine odaklanılması "metinlerin temelindeki sosyal gücün ve baskınlığın doğasını anlamımızı sağlamaktadır” (van Dijk, 1993: 254). Bu noktada söylem çözümlemesi, haber metinlerindeki anlamların ikinci bir okumasını yaparak haber söylemi içerisindeki ideolojik anlamlandırmayı ortaya çıkarmaktadır.

$\mathrm{Bu}$ çalışmanın konusuyla ilgili kaynak taraması yapılırken terör haberleriyle ilgili niceliksel veya niteliksel pek çok çalışma yapıldığı görülmüştür. Terör ve terör haberleri ile ilgili farklı çalışmalara baktığımızda ise örneğin, Duruoğlu’nun (2007) "Haber Yapmada İdeoloji Etkeni: 11 Eylül Olayı Üzerine Bir İnceleme” adlı çalışmasında Hürriyet ve Akit gazetelerinin sahip olduğu bakış açıları ile 11 Eylül terör olayını haberleştirmedeki tutumları arasında anlamlı bir ilişki tespit edilmiştir. Çalışmanın sonucunda her iki gazetenin de olaya yönelik haberleri düşünsel çerçeveleri etrafında şekillendirdiği ve dolayısıyla yansız, tarafsız ve ideolojiden bağımsız bir şekilde haberlerin oluşturulmadığı ortaya konmuştur. Aydın'ın (2012) "Türk Basınında Nefret Söylemi: Mavi Marmara Baskını Örneği” adlı çalışmasında İsrail'in Gazze'ye insani yardım malzemeleri taşıyan Mavi Marmara Gemisine yaptığı silahlı saldırı ile ilgili haberlerin Taraf, Vakit, Yeni Şafak ve Zaman gazetelerinde haber söylemlerinin hangi çerçevede oluşturulduğu ve şekillendirildiği eleştirel söylem analizi yöntemi ile analiz edilmiştir. Araştırma sonucunda, dört farklı gazetenin saldırı ile ilgili haberleri kamuoyuna aktarırken nefret söylemi çerçevesinde haberleştirdiği ve sunduğu tespit edilmiştir. Aynı zamanda, gazetelerin siyasal eğilimlerine göre nefret söylemlerinin şiddetinin değişiklik gösterdiği ve sürekli ön planda tutulduğu sonucuna ulaşılmıştır.

Özdemir’in (2016) "Rehine Krizi ve Ana Akım Medyanın Terör Eylemlerine Yaklaşımı” isimli çalışmasında 31 Mart 2015 tarihinde Çağlayan Adliyesi'nde DHKP-C örgütü üyelerince rehin alınan ve sonrasında öldürülen Savcı Mehmet Selim Kiraz’a ilişkin iletilerin Hürriyet, Cumhuriyet, Akit, Yeni Şafak ve Birgün gazetelerinde nasıl ele alındığı içerik analizi yöntemiyle incelenmiştir. Araştırma sonucunda yaşanan terör olaylarının, yayın organlarının düşünsel çerçevesinin etrafında şekillenerek haberleştirildiği sonucuna ulaşılmıştır. Girgin'in (2017) “Türkiye'deki Canlı Bomba Saldırılarını Ulusal 
Gazeteler Üzerinden Okumak” adlı çalışmasında 20 Temmuz 2015-19 Mart 2016 tarihleri arasında ülkemizde gerçekleştirilen canlı bomba saldırılarının haber fotoğraflarındaki sunumu Sabah, Yeni Akit ve Birgün gazeteleri ele alınarak göstergebilimsel çözümleme yöntemi ile incelenmiştir. Araştırma sonucunda gazetelerde kullanılan haber fotoğraflarının basın organlarının ideolojik yapısı çerçevesinde oluşan göstergeler olduğu; dönemin kültürel ve politik yapısı ile haber dili arasında bir bağ olduğu belirlenmiştir. Melek ve Toker’in (2017) "Şiddet, Demokrasi ve Terör Bağlamında Ana Akım Medyanın Analizi: 15 Temmuz Darbe Girişimi” isimli çalışmasında ise ana akım medyada yer alan Hürriyet, Milliyet, Cumhuriyet ve Sabah gazetelerinin web sitelerinde darbe girişimine yönelik haberler içerik analizi yöntemiyle incelenmiştir. Haberlerde daha çok terör ve şiddet temalarının yoğun olarak kullanıldığı ve siyasi aktörlerin kullandığı dil ve tanımlamalarının haber diline yansıdığı sonucuna ulaşılmıştır. Karabulut ve Akdumangiller'in (2018) "İnternet Gazeteciliği ve Haber Söylemi: Reina Saldırısı Haberlerinin Çözümlemesi” adlı çalışmasında 1 Ocak 2017 tarihinde İstanbul Ortaköy'deki gece kulübü Reina'ya düzenlenen saldırının internet haberlerinde yer alan haber metinlerinin söylem çözümlemesi yapılarak terör olaylarının internet ortamında nasıl ele alındığı incelenmiştir. Çalışmanın sonucunda, internet haber sitelerinin haber sunumu ve yazımı noktasında benzeştiği ancak ideolojik yapılarına göre söylemlerinin farklı olduğu belirlenmiştir. Gölcü ve Olkun'un (2018) "Terör Saldırılarının Haberleştirilmesinde Gazete Yayın Politikalarının Etkisi” adlı çalışmasında gazete yayın politikalarının terör saldırılarında kullanılan haber dili ve söylemine etkisi araştırılmıştır. Araştırmada, Birgün ve Evrensel gazetelerinin “10 Ekim 2015 Ankara Tren Garı’nda ve 13 Mart 2016 Güvenpark’ta gerçekleştirilen terör saldırısını ele alışları söylem analizi yöntemi incelenmiştir. Araştırma sonucunda her iki gazetenin de haber sunum ve söylemlerinde, iki farklı terör saldırısını aktarırken farklılıklar gösterdiği görülmüştür. Tüm bu çalışmalar, 15 Mart 2019 tarihinde Yeni Zelanda'da meydana gelen terör saldırısı ile ilgili haber metinlerinin van Dijk’’n söylem analizi yöntemiyle incelenmesine ve araştırmanın genel çerçevesinin çizilmesine yardımcı olmuştur.

\section{Amaç ve kapsam}

Bu çalışmada; birbirinden farklı yayın politikalarına ve siyasal eğilimlere sahip gazetelerin terör eylemlerinin haberleştirilme sürecinde haber dili ve söylemine etkisini ortaya koymak amaçlanmıştır. $\mathrm{Bu}$ amaç doğrultusunda; farklı eksenlerde yayın yapan gazetelerin aynı olayı nasıl bir dil ve söylemle inşa ettiği ve sunduğu, gazete yayın politikalarının haber dili ve söylemine etkisi üzerinden analiz edilerek ortaya konmuştur. Çalışma kapsamında; belirlenen konu üzerinden terör eylemlerinin haberleştirilme sürecinde, gazete yayın politikalarının haber üretim sürecine, haber dili ve söylemine etkisi üzerinde durulmuştur. Bu kapsamda, 15 Mart 2019'da Yeni Zelanda'nın Christchurch kentinde Cuma namazı sırasında iki camiye düzenlenen silahlı terör eylemi örnek olarak seçilmiştir. Çalışmada, araştırmanın evreni Türkiye'de yayın yapan gazeteler oluşturmaktadır. Araştırmanın örneklemini; birbirinden farklı yayın politikalarına sahip olan Yeni Akit, Orta Doğu, Yeni Şafak, Milli Gazete, Sözcü ve Cumhuriyet gazetelerinin 16 Mart- 23 Mart 2019 tarihleri arasında bir haftalık süre içerisinde yayımlanan söz konusu terör haberleri oluşturmaktadır. Haberler belirlenirken gazetelerin ilk sayfaları daha çok okunduğu ve dikkat çektiği için sadece ilk sayfa haberleri ve bu haberlerin iç sayfalardaki yansımaları incelemeye tabi tutulmuştur. Sonuç olarak aynı olayın, birbirinden farklı bakış açılarına sahip gazetelerde, farklı dil ve söylem kalıpları ile haberleştirildiği tespit edilmiştir.

\section{Araştırmanın yöntemi ve sınırlılıkları}

Bu çalışmada; gazete yayın politikalarının haberin üretim sürecine, dili ve söylemine ve etkisi, 15 Mart 2019'da Yeni Zelenda'da gerçekleşen terör saldırısı örneği üzerinden Teun van Dijk’’n söylem analizi 
Looking for the language and discourse practices in news texts: New Zealand terror attacks case / A. Gölcü; E. Bal; B. Karadeniz (pp. 220-251)

yöntemi kullanılarak incelenecektir. Bu yöntemin seçilmesinin nedeni; haberin yapısını, sunumunu derinlemesine inceleyerek eşitsizliğin ve egemenliğin yeniden üretiminde söylemin rolünü ortaya çıkarmaya çalışmasıdır. Gerçekliğin yeniden kurgulandığı haber metinlerinin temelinde, haberde tercih edilen dil ve söylemler aracılığıyla olaylar/gerçekler aktarılırken, aynı zamanda haber söyleminde egemen ideoloji doğallaşmakta ve yeniden kurulmaktadır (Tokgöz, 2003: 185). Çünkü söylemler aracılığıyla insanların zihinlerini kontrol etmek, egemenliği yeniden üretmenin dolaylı, ama en temel yolunu oluşturmaktadır (van Dijk, 2015: 472). Bu bağlamda metin ve konuşmalarda egemen ideolojilerin söylemler aracılığıyla edinilmesi, ifade edilmesi, yürürlüğe konulması ve yeniden üretilmesi ise bir dizi söylemsel yapı ve strateji ile gerçekleşmektedir (van Dijk, 2006: 124). Metindeki içeriğin analiz edilmesi, metne içerilmiş anlamların, kullanılan dilsel birimler (sözcükler, tümceler vb.) aracılı̆̆ıla incelenerek dilin görünürdeki anlamlarının arkasında gizlenen mesajın ortaya çıkarılması ise söylem analizi yöntemi ile mümkün olmaktadır (Güngör, 2013: 242). Söylem çözümlemesi, tahakkümün söylemsel olarak yeniden üretilme sürecine odaklanarak, metin ve konuşmalarda hangi söylem yapılarına ve stratejilerine başvurulduğunu incelemekte ve aynı zamanda toplumsal yapının ve iktidar ilişkilerinin metindeki izdüşümünü bulmayı amaçlamaktadır (Evre, 2009:141; Doyuran, 2018:315). Bu bağlamda van Dijk’’n söylem çözümlemesi ise sosyal düzeni özellikle de eşitsizlik ilişkilerini meşru kılan veya meşrulaştırıcı söylemsel stratejiler üzerine odaklanarak egemenliğin söylemsel pratikler üzerinden yeniden üretimini incelemektedir (van Dijk, 1993: 254).

van Dijk, metnin söylem çözümlemesini sentaktik ve semantik olmak üzere iki dilsel çözümleme olarak ayırmaktadır. Sentaktik çözümlemede, analiz birimi olarak haber metninde kullanılan cümlelerin gramatik yapılarına odaklanılırken, semantik çözümlemede sözcüklerin, cümlelerin, kısaca bütün söylemin anlamına odaklanılmaktadır (Doruk, 2013:115). Bu açıdan ele alındığında van Dijk’ın söylem çözümlemesi modeli, makro ve mikro yapı olmak üzere iki ana bölümden oluşmaktadır. Günlük etkileşim ve deneyim içerisinde makro ve mikro düzeylerin birlikte bir bütün oluşturduğunu düşünen van Dijk; dil kullanımı, söylem, sözlü etkileşim ve iletişimi toplumsal düzenin mikro analiz düzeyinde ele alırken, toplumsal gruplar arasındaki iktidar, tahakküm ve eşitsizliği makro analiz düzeyine ait olarak değerlendirmektedir (van Dijk, 2015: 468). Kendi arasında tematik ve şematik çözümlemeden oluşan makro çözümlemede ilk olarak van Dijk, tematik çözümlemeyi; üst başlık, başlık, alt başlık, spot ve haber girişi olarak değerlendirmektedir. Üst şema örgütlenmesi olarak değerlendirilen bu tarz bir yapılanma, hikâye etmeye; yani olayı anlatma ve haber raporlarından oluşan bir şema izlemeye dayanmaktadır (Sözen, 2014: 122). Bu bağlamda başlık, spot ve haber girişinden oluşan klasik haber incelemesi, haberde genelden özele, en önemli bilginin önce verilmesinden, önemsiz detaylara doğru bir gidiş olduğuna işaret etmektedir (Yegen, 2014: 322). Hiyerarşik bir yapılanmaya göre oluşturulan haberler, başlık ve haber girişi ile okuyucuya olay hakkında bir özet sunmakta ve genel bir çerçeve çizerek haberin temasını sınırlandırmaktadır. Bu noktada kamuoyuna sunulan bilgiler, bir bakış açısı, bir ideolojik yaklaşım doğrultusunda seçilerek bir araya getirilmiş bilgilerin örgütlenişinden oluşmaktadır (Güngör, 2013: 250). Dolayısıyla haberlerde kullanılan bu tematik unsurlar, bazı temaları ve konuları ön plana çıkararak haberlerin belirli çerçevelerle okuyucu kitleye aktarılmasında rol oynamaktadır. Diğer yandan makro çözümlemenin bir diğer kategorisi olan şematik çözümlemede; ana olay, haber girişleri, haber kaynakları, tarafların olaya ilişkin değerlendirmeleri, ardalan ve bağlam bilgisi yer almaktadır. Mikro çözümlemede ise van Dijk; sentaktik çözümleme, kelime seçimleri, bölgesel uyum ve haber retoriğini incelemiştir. Bu bağlamda mikro çözümleme; haberde kullanılan cümle yapısının kısa veya uzun olmasını, etken-edilgen oluşunu, seçilen kelimelerin kültürel ve ideolojik anlamlarını, cümlelerin birbiriyle olan ilişkisini ve haberin inandırıcılığını arttıran retoriksel (fotoğraf, grafikler, istatistikler, alıntıya başvurma vb.) boyutunu kapsamaktadır. Mikro çözümlemede kelime seçimleri, haber söylemindeki ideolojik etkinin ortaya çıkarılmasında önemli rol oynamaktadır. Çünkü 
seçilen kelimeler gazetecinin sınıfsal konumunu yansıtabildiği gibi aynı olayın farklı betimleyici ifadelerle tanımlanması da medya kuruluşunun ideolojisini yansıtabilmektedir. Aynı zamanda haberin retorik çözümlemesinde ise haberin inandırıcılı̆̆ını sağlamak için kullanılan fotoğraflar, abartma, küçültme ve zitlık ifadeleri ile ilgilenilmektedir. Genel bir ifade ile söylem analizi; medya söyleminin üretimi ve anlamı altında yatan kurallar ve stratejiler hakkında sosyal ve bilişsel bilgi sağlayarak ideolojinin yeniden üretiminde söylemin rolünü açıklamaktadır (van Dijk, 1983: 27).

Bu çalışmada daha önce de belirtildiği üzere van Dijk’’n söylem analizi yöntemi kullanılarak, gazete yayın politikalarının terör haberlerinin söylemine ve haber üretim sürecine etkisi, haber metinlerinde kullanılan dil ve söylem üzerinden incelenerek analiz edilecektir. Çalışmanın zaman sınırlılığı; terör saldırısının haberleştirildiği sonraki ilk bir hafta (16 Mart-23 Mart 2019) olarak belirlenmiştir. Ayrıca araştırma, belirlenen gazetelerin baş sayfalarında konuyla ilgili yayınladıkları haberler ile sınırlandırılmıştır.

\section{Medya ve terör ilişkisi}

Terörizm; bir hükümete, geniş bir topluma, sempatizanlara, muhtemel yeni üyelere, kendi hareketlerine/organizasyonlarına yani çoğul izleyicilere mesaj göndermeyi amaçlayan iletişimsel bir eylemdir (Elshimi, 2018: 2). Sürekli farklılaşan ve durağan olmayan terörün amacı, belirlenen hedeflere ulaşmak için eylemleri ve stratejileri doğrultusunda şiddet kullanarak toplumda korku iklimi oluşturmak, kamusal dikkati ve ilgiyi çekerek varlıklarını en etkili şekilde göstermektir. Bu anlamda terör eylemini gerçekleştirenlerin amaçlarına ulaşmak ve seslerini duyurabilmek için propagandaya ihtiyaçları vardır. Bu noktada etkili bir propaganda için toplumsal yıldırma ve korkutmanın yaratabileceği en uygun ortamı sağlayan, sosyal yaşamın her alanına nüfuz eden, kitlesel iletişime olanak veren medyanın gücü gereklidir (Yüksel, 2006:36). Gelişen teknolojiyle birlikte kitle iletişim araçları, dünyanın herhangi bir yerinde meydana gelen olayları hızlı ve güncel bir şekilde kitlelere aktarabilmenin en kolay ve en önemli yoludur. Dolayısıyla terör olgusunun gündemdeki yerini koruması ve etki alanını genişletmesi, günümüz dünyasında medyada yer aldığı ölçüde değişim göstermektedir. Yani teröristler, eylemlerini gerçekleştirirken başarının olmazsa olmaz şartlarından birisi olarak medyatikliği tercih etmektedirler (Avşar, 2002: 27).

Temelde teröristler, medyanın çalı̧̧ma yönteminden istifade ederek geniş bir izleyici kitlesine erişmektir (Martin, 2008: 135). Teröristler, medyayı genellikle kendi iletişim amaçları için, hükümetlerin ve diğer izleyicilerin dikkatini çekmek için kullanırlar (Crelinsten, 2013: 316). Bu bağlamda hesaplı ve sistematik bir yapıya sahip olan terör eylemleri, amaçları ve hedefleri doğrultusunda yasal yollarla elde edemeyeceği güce medya aracılı̆̆ıla kitleler üzerinde korku ve ümitsizlik yaratarak sahip olmaya çalışmaktadır. Böylece terörizm, başka yöntemlerle iletmekte pek başarılı olamadıkları tekliflerini, mesajlarını medya aracılı̆̆ıyla ileterek kendilerini seyreden "tarafsız" insanlar üzerinde korku ve dehşet yoluyla derin psikolojik izlenimler bırakarak yaratmaya çalışmaktadır (Ergil, 1991: 174). Bu anlamda terörizm, daha geniş bir topluma tehdit içerikli mesajların iletilmesine dayanan psikolojik bir silahtır (Wilkinson, 1997: 54). Bir başka ifade edişle küreselleşmeyle birlikte günümüz dünyasında terör hareketleri, medya üzerinden eylemlerinin mümkün olduğunca çok insana duyurulmasını sağlayarak kamuoyunun dikkatini çekmeye çalışmakta ve kendi lehine propagandasını yapmaktadır. Böylece kamuoyunun gündemini kendi hedefleri doğrultusunda yönlendirerek varlıklarına alenilik kazandırmaya çalışmaktadırlar. Aynı zamanda popülarite kazanarak insan kaynağı ihtiyacını da bu doğrultuda sağlama imkanına kavuşmaktadır. 
Looking for the language and discourse practices in news texts: New Zealand terror attacks case / A. Gölcü; E. Bal; B. Karadeniz (pp. 220-251)

Teorik olarak teröristlerin amacı kitle katliamı değildir; rastgele ya da sembolik olarak seçilmiş mağdurlar aracilı̆̆ıyla daha çok kitlelerin kendilerini seyretmesini, dinlemesini ve böylece eylemlerinden etkilenilmesini sağlamaktır (Yayla, 1990:342). Çünkü bir terör eyleminin etkisi kitlelerin ve medyanın dikkatini çektiği ölçüde başarılı ya da başarısız olarak kabul edilmektedir. Bu bağlamda her türlü propagandanın en önemli aracı olarak sayılabilecek medya, toplumsal bir yıldırma, korkutma ve endişenin en iyi yaratılacağı ortamı sunmak ve terör örgütlerinin sesini kitlelere duyurmanın en kolay ve en etkili yoludur (Akçar ve Çelenay, 2012:184). Bu anlamda medya ve terör eylemleri arasında çıkar ilişkisine dayanan karşıllklı bir etkileşim söz konusudur. Medya kuruluşları, terör olaylarını kendi çıkarları doğrultusunda kamuoyuna aktarırken, terör örgütleri eylemlerini halka duyurmak amacıyla medyayı bir araç olarak kullanmaktadır. Yani terör örgütlerinin propaganda amacı ile medyanın reyting kaygısı birbirini besleyen bir ilişki ağı oluşturmaktadır (Kazan, 2016:111). Medyanın terör eylemlerini en güncel ve hızlı bir şekilde kamuoyuna iletmesinin temel nedeni ekonomik çıkarlarken, terör örgütlerinin ise seslerini ve eylemlerini medya aracllı̆̆ıla duyurarak hedef kitle üzerinde arzuladıkları hedefe ulaşmaktadır. Bu doğrultuda terörist gruplar, ideolojilerini ve doğru olduğuna inandıkları öğretilerini yaymak için kitle iletişim araçlarını kullanmaktadır (Putra, 2016: 4).

Medyanın kamuoyunu eğitme, eğlendirme, siyasal sürece katılmalarını sağlama ve denetleme gibi işlevlerinin yanı sıra temel görevi insanlara doğrudan tanık olamayacakları olaylar hakkında bilgi ve enformasyon sağlamaktır. Ancak medya kuruluşlarının; işletme ve örgütlenme biçimlerinin kâr odaklı değişmesiyle birlikte giderek artan ekonomik kaygılardan ve sahiplik yapısından kaynaklanan baskıdan dolayı en çok izlenen, okunan ve dinlenen ilgi çekici haberlere ihtiyaç duymaktadır. Bu bağlamda günlük hayatımızda sıkça karşılaşmadığımız terör eylemleri, temelde bir ticari işletme olan medya organizasyonları için önemli bir malzeme ve toplumu yakından ilgilendiren hadiselerden biridir. $\mathrm{Bu}$ olaylar, medyanın daha çok izleyiciyi/okuyucu çekebilmesi için gerekli olan tehlikeye, dramaya, insana dair trajedilere, şok edici görüntülere, mucize hikâyeler ve kahramanlar gibi öğelere sahiptir (Avşar, 2017:122). Bu anlamda terör eylemleri, her ne kadar şiddet ve tehdit içerikli de olsa medya kuruluşları için haber değeri taşımaktadır. Ancak bu ilişki ağında önemli olan nokta ise kamuoyunu bilgilendirme görevini üstlenen medyanın, terör haberlerini nasıl haberleştirdiği ve kamuoyuna nasıl aktardığıdır. Çünkü okuyucular/izleyiciler için olayların anlaşılabilir kılınması, medya profesyonellerinin bunları toplumsal bir bağlama oturtması, sosyal ve kültürel bir kimliğe büründürerek tanımlaması ile gerçekleşmektedir (Cangöz, 2008:85). Bu çerçevede terör eylemlerinin ulusal ve uluslararası güvenliğe yönelik tehditler içermesi nedeniyle haberleştirilme sürecinde neyin haber, neyin propaganda olduğu noktasında bir ayrım yapılması gerekmektedir. Medya kuruluşlarının terör eylemlerini nasıl haberleştirdiği, haber metni için tercih edilen durum tanımlamaları, dil yapısı, söylem ve çerçeveleme gibi birçok faktör önem kazanmaktadır (Gölcü ve Olkun, 2018:171).

Kamuoyunun bilgi edinimi ve kanaat oluşumunda etkili olan medya kuruluşlarının bürokratik yapılanmaları, olay veya olayların farklı bakış açılarıyla tanımlanmasına, yorumlanmasına, çerçevelenmesine yol açmaktadır. Daha net bir ifade ile her medya kuruluşu kendi yayın politikaları çerçevesinde bu olaylara bir etkide bulunarak kamuoyuna aktarmaktadır. Dolayısıyla medya organizasyonlarının kalite ve prestijlerinin yanı sıra, güvenirliklerinin de garantisi olan haberler; toplumun bilgi ve ilgisini geliştirecek, dönüştürecek, gerçekliğin kurgusal olarak yayımlanacak medya organizasyonunun yapısına, teknolojisine ve ideolojisine göre "yeniden" kurgulanmaktadır (Yurdigül ve Balcı, 2011:284). Bu noktada medya organizasyonlarının terör eylemlerini gerçekleştirenleri nasıl tanımladığı, olaylara yaklaşımı ve duruşu önem taşımaktadır. Çünkü bu olaylar medya kurumlarının bakış açılarına göre şekillenmekte ve aynı olay farklı tanımlamalarla ifade edilebilmektedir. Örneğin, terör eylemini gerçekleştirenler bir medya kuruluşuna göre terörist ya da gerilla, diğerine göre 
vatansever ya da özgürlük savaşçısı olarak tanımlanabilmektedir. Bu durum ise terör eylemlerinin kamuoyu üzerinde etkililiğin artmasında ya da azaltmasında rol oynamaktadır. Çünkü olayların kamuoyuna anlatılması ve aktarılması, medya kuruluşlarının haber söylemine dayanmaktadır.

\section{Söylem ve haber metinlerinde söylem}

Yirmi birinci yüzyllın söylem çağı olduğunu ifade eden Sözen'e (2014:9) göre Newton’un mutlak zaman ve uzayı içinde değil, belirsiz ve kaotik bir söylemler dünyası içinde yaşamaktayız. Bu anlamda söylem kavramı, farklı akademik disiplinlerin farklı yaklaşımlara dayanarak açıklamaya çalıştığı bir kavram olarak karşımıza çımaktadır. Beşerî ve sosyal bilimlerin kesiştiği bir alan olarak söylemin birbirinden farklı birçok tanımı yapıldığı gibi, başta dil ve metin olmak üzere ideolojiden dine, politikadan hegemonyaya kadar geçmişten günümüze pek çok kavramla ilişkilendirilmiştir (Aydın, 2013:54). Genel bir ifade ile Türkçe'de söylem kavramı etkili söz söylem sanatı, anlatım biçimi, açıklama, ideoloji, yazılı ve sözlü ifade, hitabet, tez, bakış açısı, sav, görüş, felsefe, üslup, telaffuz, kavramsal dizge, işaretler toplamı gibi farklı anlamlarda oynak bir zeminde tanımlanmaktadır (Kocaman, 2003:5). Bu anlamda söylem terimi, tek bir temele dayanan tutarlı bir tanıma sahip değildir.

Söylem en basit ifade ile bir dil pratiği olarak tanımlanabilir ve anlamın dil içinde hareket etmesiyle ortaya çıkan dilsel bir pratik olarak ifade edilebilir. Dilbiliminde dilin kullanım biçimi olarak tanımlanan söylem, aynı zamanda dil pratiklerinin yanı sıra sosyal, siyasi, kültürel, ekonomik alanlar gibi sosyal hayatın diğer yönleriyle de ilişkilidir (Devran, 2010: 25; Sözen, 2014:18). Söylem bir meta-eylemdir ve ideoloji, bilgi, diyalog, anlatım, beyan tarzı, müzakere, güç ve gücün mübadelesiyle eyleme dönüşen dil pratiklerini içeren bir süreci kapsamaktadır (Çelik ve Ekşi, 2008:100). Bir dünya tasavvuru sunan söylem, başka bir ifade edişle ait olduğu öznenin dünya üzerindeki yerini, geleceğini, toplumsal mücadelesini dil yoluyla meşrulaştırma çabasıdır (Yılmaz, 2013:27). Söylemin anlam kazandığı dil ise mesajı, düşünceyi ve ideolojiyi taşıyan temel bir araçtır (Devran, 2010:24). Bu açıdan ele alındığında bilginin dildeki kullanımı, gücün dildeki kullanımı, ideolojinin dildeki kullanımı, birer dil eylemidir ve bunların fonksiyonelliği, ancak bir söylem içinde anlamlı hale gelmektedir (Sözen, 2014:10).

Gürses'e (2017:90) göre insanların, çeşitli gündelik pratiklerini yerine getirdikleri dil alanında gelişen söylem, dünyanın anlaşılması için dünyadaki nesnelerin anlamlandırılabilir kavramlara dönüştürülmesini sağlamaktadır. Kavramların anlamlandırılma sürecinde var olan gerçeklik ise dilsel pratikler yoluyla desteklenip üretilmekte ve temsil edilmektedir (Poyraz, 2002:17). İdeolojinin maddi bir biçimi olan dil ise ideoloji tarafından şekillendirilmektedir (Fairclough, 2015:124). Bu süreçte ideoloji, gerçekliği kodlama sistemi olarak dil ile yeniden inşa edilmekte ve iletilmektedir (Devran, 2010:26). Bu anlamda gerçekliğin söylemler aracılı̆̆ıyla yeniden inşa edildiği 21. yüzyılda söylemler ideolojilerle birlikte çerçevelenerek sunulmaktadır. Çünkü ideoloji toplumsal bir oluşum olarak ancak dil ile ortaya çıkabilmekte ve dilde anlatım imkânı bulabilmektedir. İdeolojilerin yeniden üretiminde ve günlük ifadelerimizde vazgeçilmez bir rol oynayan söylemimizin çoğu, ideolojik temelli görüşlerimizi ifade etmektedir (van Dijk, 2015:15-19). Bu durum ise ideolojileri kuşatan her söylemin kendine tekabül eden bir gerçekliği oluşturması anlamına gelmektedir. Başka bir ifade edişle söylemler ideoloji ile ilgilidir. Çünkü söylemler, egemen güce sahip olanların ideolojisini içerisinde barındırmaktadır. Egemen ideolojiyi içerisinde barındıran söylemler, böylece güçlü çıkar gruplarının iktidarını harekete geçiren, üreten, güçlendiren ve aynı zamanda çıkarlarını sağlayan bir araç olarak kullanılmaktadır. Bu bağlamda söylemler, yapısal ve içeriksel tutarlılığı olan ve sosyal bağlamda anlamı inşa etmeye olanak tanıyan dilsel malzemenin araçları olarak görülmektedir (Çelik ve Ekşi, 2008:101). Anlamın inşa sürecinde ise egemen güçler, söylemin maddi üretimini, formülleştirimini ve dağıtımını denetlemeleri 

(pp. 220-251)

sayesinde söylem üzerinde denetim oluşturabilmektedirler (van Dijk, 1999:378). Bu denetim süreci günümüzde kitle iletişim araçları ile gerçekleşmektedir.

Toplumdaki güçlü çıkar grupları ve aktörler, iktidarlarının devamını sağlamak için bilginin denetimine sahip olmak istemektedir. Çünkü günümüz toplumlarında kitle iletişim araçlarını kontrol etmek sosyal gücün çok önemli koşullarından birini oluşturmaktadır (van Dijk, 1995:11). Aynı zamanda kitle iletişim araçları, her zaman yaşanmakta olan dünyayı kendi söylemine çevirerek yansıtmaktadır (Poyraz, 2002:12). Gerçekliği yeniden kurgulayan bu araçlar ile her bilgi kendi iktidarını üretmekte ve kurmaktadır. Bu noktada ise söylem yoluyla toplumsal denetim uygulanmasının önemli bir koşulu olarak söylemin denetimi ve bizzat söylem üretimi gerekmektedir (van Dijk, 1999:335). Çünkü bu süreçte ideolojik olarak kuşatılmış söylemsel pratikler mümkün olduğunca güç ilişkilerinin sürdürülmesi ve altının oyulmasına katkıda bulunmaktadır (Fairclough, 2015:134). Bu bağlamda gerçekliğin yansıması olarak haber metinleri ise ayrı bir önem taşımaktadır.

İnsanlar çevresinde ve dünyada olan bitenler hakkında bilgi sahibi olmak istemektedir. Kitlelerin, ulusal ve uluslararası olaylar hakkında bilgilendirilmesi ise kitle iletişim araçlarının sunduğu haberler aracılığı ile gerçekleşmektedir. İnsanlar gündelik yaşamının ayrılmaz bir parçası olan medya aracıllğıyla sosyal yaşamlarını düzenlemekte ve çevresinde olan bitenleri bu araçlar vasıtasıyla değerlendirmektedir. Kitlelerin dünyaya açılan penceresi olan medyanın sunduğu "haberler, öncelikle okuyucu ve dinleyici için yeni gerçeklerle ilgili, doğru ve anlaşılır bilgiler sunmaktadır” (Schneider ve Raue, 2000:40). Ancak kitlelere sunulan bu gerçeklikler, medya aracılığıyla yeniden üretilerek tanımlanmaktadır. Yeni bir gerçeklik sunan medya, kendi bakış açısından önem atfettiği olay ve olgulara dikkat ve ilgisini yoğunlaştırmakta, böylece aynı zamanda olayların ve eylemlerin inşa edilmesi, üretilmesi ve sunulmasının temel kural, ölçüt ve yöntemlerini belirlemektedir (Gökçe ve Demiray, 2006:3). Yani medyanın insanları bilgilendirme gücü, gerçekliğin yeniden üretilmesi ve kurgulanması sonucunda kitlelere gerçekliğin temsilinin aktarılmasıyla gerçekleşmektedir. Bu noktada haberler kesinlikle saf ve basit gerçekler değildir; gerçekliğin evrimini, analizini, seçimini kapsamaktadır (Poyraz, 2002:69). Medyanın sahip olduğu bu gücün farkında olan çeşitli çıkar grupları ise bu gücü elde etmek adına birbirleri ile rekabet etmektedir. Çünkü günümüz dünyasında küreselleşmeyle birlikte her alanda yaşanan değişim medya organizasyonlarının yapısını da değiştirmiştir.

Haberciliğin niteliği, kamuoyuna verilen haberlerle bilgilendirme ve bilinçlendirmenin yerini çıkar grupları ve aktörlerin kâr elde etme isteğine bırakmıştır. Bu değişim beraberinde, egemen çıkar gruplarının haberleri bir mal gibi alınıp satılabilen ürün olarak görmeye başlamasına neden olmuştur. Böylece endüstriyel ilişkilerin belirleyici olduğu medya sektörünün ilk amacı halkı bilgilendirmek değil, kâr elde etmek olmuştur. Dolayısıyla medya kuruluşları kendi çıkarları doğrultusunda haberlere bir etkide bulunarak gerçekliği yeniden inşa etmektedir. İstedikleri bilgiyi dolaşıma sokarken, istemedikleri bilgiyi ise gizlemektedir. Bu bağlamda haber verme bakımından medya kuruluşları ile toplum arasında tek yönlü bir iletişim söz konusudur. Bu tek yönlü iletişimin gücünün farkında olan egemen çıkar grupları ve aktörler, iktidarlarını devam ettirmek için kamuoyunu bilgilendirme görevini üstlenen ve aynı zamanda içerisinde belli ideolojik düşünceleri taşıyan, yapılandırılmış bir metin olarak haber metinlerini kullanmak istemektedir. Bu noktada hangi olayın ya da olayların haber olarak aktarılacağı medyanın sahip olduğu yayın politikasına göre değişmektedir. Çünkü çoğu kamu söyleminde olduğu gibi haberlerde ideolojilerle doludur ve bu nedenle kamu söyleminin özellikle de kitle iletişim araçlarının içeriğine ve yapılarına erişimi kontrol eden seçkin gruplar, güçlerini devam ettirmeye yardımcı olan ideolojilerin oluşmasını ve çoğalmasını da kontrol edebilmektedir (van Dijk, 2009: 202). Dolayısıyla medyanın kurumsal yapısı, daha en başından haberlerde gerçeğin bire bir yansıtılmasını imkânsız hale 
getirerek, kitlelere gerçekliğin yanıltıcı bir yansımasını sunmakta ve doğrudan nasıl düşüneceklerini belirleyemese dahi, neler üstüne düşünmeleri gerektiğinin çerçevesini çizmektedir (Talu, 2000: 31, 37). Daha net bir ifade ile medya profesyonelleri haber öykülerinin nasıl bir çerçeveye oturtulacağına "seçme" veya "eleme" yoluyla karar verirken aynı zamanda olayın nasıl anlaşıl(ma)ması gerektiğine de karar vermeye; haberin okunuşunu/yorumlanışını belirli bir tarzda yönlendirmeye çalışmaktadır (Kılıç, 2008: 52). Bu şekilde gerçekleştirilen haber üretimi ise söylemsel bir süreç haline gelmektedir (Hout ve Jacobs, 2008: 64). Bu nedenle haberin aktarımında sıklıkla vurgulanan nesnellik kavramı, arzu edilen bir düşünce olmaktan ileri gidememektedir. Çünkü bir haber, üretiminden dağıtımına kadar medya organizasyonun belirlediği kodlar çerçevesinde hazırlanmaktadır. Bu kodlar ise medya kuruluşlarının yayın politikası çerçevesinde şekillenmektedir. Dolayısıyla bir medya kuruluşuna baktığımızda, oluşturulmuş roller ve bunlara uygun yapılanma, bu yapılanmayı izleyen politikalar ve bu politikaların sürdürülmesini sağlayan güçler söz konusudur (Küçüközyiğit, 2014: 96). Özellikle de haber ajansları, editörler ve muhabirler, olayları sıralayan ve neyin önemli bir hikâye olmadığını tanımlayan eşik bekçileri olarak hareket etmektedir (Andrews ve Caren, 2010: 843). Yani bir haberin söyleminin oluşmasında haber kaynağı, haberin üretildiği kurumun ve toplumun ekonomi politiği, haber profesyonelleri ve editoryal süreç, belirleyici bir rol oynamaktadır (Karaduman ve Batu, 2011: 363).

Shoemaker ve Reese, haber içeriklerine etki eden unsurları geliştirdikleri "Etkiler Hiyerarşisi" modeli çerçevesinde açıklamaya çalışmıştır. Bu modele göre haber seçme/eleme kararında etkili olan unsurlar ilk boyuttan başlayarak medya çalışanlarından kaynaklanan etkiler (gazetecinin kendisi), medyanın tek düze çalışma düzeninden kaynaklanan etkiler, medyanın kurumsal yapısından kaynaklanan etkiler, medya içeriğine dışardan gelen etkiler ve ideolojik yapıdan kaynaklanan etkilerden oluşmaktadır (Rigel, 2000: 25-26). Başka bir anlatımla haber içeriklerini; medya çalışanlarının kişisel özellikleri ve tutumları, medya kuruluşlarının sahip olduğu rutinler ve işlerin nasıl organize edileceğini belirleyen kısıtlayıcı yapısı, ekonomik, politik ve kültürel güçlerin içeriğe yansıması, statükoyu koruyan ideolojik konumların etkisi belirlemektedir (Reese, 2007: 34-35). Bu faktörlerin haber içeriklerini etkileme düzeyleri mikro seviyeden makro seviyeye doğru değişim göstermektedir. Yani en küçük boyutu oluşturan medya çalışanları, haber içeriğini diğerlerine göre en az etkileme düzeyine sahipken, en büyük boyutu oluşturan ideolojik yapı ise en önemli etkiyi oluşturmaktadır (Deniz ve Özel, 2018: 918). Medya herhangi bir konuyu aktarırken, konuya farklı bir açıdan bakıp asıl görmesi gereken konuyu görmezlikten gelebilir ve farklı şekilde yeniden inşa edebilir (Gadimov, 2015: 219). Bu anlamda Edward Herman ve Noam Chomsky, medya kuruluşlarının çıkarlarını koruma doğrultusunda haberin içeriğine çeşitli düzeylerdeki etkisini ekonomi-politik yaklaşım çerçevesinde açlklamaktadır. Herman ve Chomsky, geliştirmiş oldukları "Propaganda Modeli" beş temel haber eleme süzgeçlerinden oluşmakta ve güç, sermaye, iktidar ve çıkar ilişkilerini temel almaktadır. Bu model, medya tarafından neyin haber olarak tanımlanacağına ya da tanımlanmayacağına etki eden faktörleri ortaya koyarak, medyanın belirli bir düzen çerçevesinde işlediğini açığa çıkartmaktadır. Modelin temellendiği haber eleme süzgeçleri ise; (1) egemen medya şirketlerinin büyüklüğü, yoğunlaşmış mülkiyeti, kar amaçlı oluşu ve sahiplerinin serveti, (2) reklamcılığın medyanın en önemli gelir kaynağı olması, (3) medyanın iki temel kaynak ve iktidar odağı olan hükümet ile iş çevrelerinden ve bunların mali destek sağlayıp onayladığı uzmanlardan sağladığı bilgileri temel alması, (4) medyayı hizaya sokmak amacıyla kullanılan bir yöntem olan 'medyaya yönelik tepki üretimi', (5) ulusal bir din ve denetleme mekanizması olan 'anti-komünizm'dir (Chomsky ve Herman, 1998: 22). Bu süzgeçler, medyanın haberleri işleyişinde etkili olmakta; neyin halka duyurulacağı ya da gizleneceği konusunda belirleyici rol oynamaktadır. Sonuç olarak haber söylemleri, birçok faktörün birbiriyle etkileşimi sonucunda ortaya çlkmaktadır. Bu bağlamda haber içeriği ve buna bağlı olarak söylem, her aşaması en başından itibaren belirli olan kodlar çerçevesinde düzenlenmekte ve bunun sonucunda belli dünya görüşlerini taşıyan ideolojik bir yapıya sahip 
olmaktadır. Bu noktada medya kuruluşları tarafından belirli kodlar çerçevesinde üretilen haberlerde kullanılan dil ve söylemler, medyanın tarafsız ve objektif olmasını engellediği gibi haber metinlerinde medya kuruluşlarının ideolojisinin izlerini de görünür kılmaktadır (Gölcü ve Olkun, 2018: 177).

\section{Bulgular}

\section{Cumhuriyet gazetesi}

\section{Makro analizi:}

Cumhuriyet gazetesi, 16 Mart tarihli sayısında yaşanan terör saldırısını "Yeni Zelanda'da Irkçı ve İslam Karşıtı Terörist 2 Camide Katliam Yaptı” üst başlığıyla ve “49 Ölü” ifadesiyle okuyucularına aktarmıştır. Gazete, saldırıyı gerçekleştiren kişiyi "Irkçı ve İslam karşıtı terörist" olarak tanımlarken, haberin manşetinde ise saldırıyı "Barbarlık" olarak ifade etmiştir. Bu bağlamda gazetenin yapılan terör saldırısını "terör saldırısı" olarak tanımlamak yerine, "katliam" ve "barbarlık" olarak tanımladığı görülmektedir. Gazete, haberin üst başlı̆̆ında, okuyucularına saldırı hakkında özet bir bilgi aktarırken, "Katliama Canlı Yayın”, "Ardern: En Kara Gün” gibi ara başlıklarla devam eden haberde saldırının gerekçelerine dair herhangi bir ardalan bilgisine yer vermemiştir. Bu bağlamda gazete, haberin genelinde bütüncül bir söylem oluşturamamıştır ve saldırının ana nedenleri yerine detaylar üzerinden bir anlatımı tercih etmiştir. Haber için tercih edilen ilk görselde, sedye ile ambulansa taşınan bir yaralının görseli tercih edilirken; ikinci görselde ise bir erkeğin fotoğrafı yüzü buzlanmadan verilmekte ve "poliste kaydı bulunmayan cani" ifadesi ile tanımlanmaktadır. Bu bağlamda gazete, haber içeriğinde saldırıy gerçekleştiren kişinin terörist Brenton Tarrant olduğunu belirtirken; fotoğrafı kullanılan kişinin ise saldırıyı gerçekleştiren kişi olup olmadığı noktasında net bir bilgiye sahip olmadığı gözlemlenmektedir.

Cumhuriyet gazetesinin 17 Mart tarihli sayısında saldırısı sonrası yaşanan gelişmeler, "Yeni Zelanda Teröre Karşı Kenetlendi” üst başlı̆̆ıyla okuyuculara aktarılmıştır. "Dünya Daha Netini Görmedi” manşetiyle devam eden haberde gazetenin, saldırıya yönelik değerlendirmede bulunan profesörün açıklamaları üzerinden saldırının İslamofobik olduğu ve nefret saldırılarının aşırı sağın yükselmesi ile bağlantılı olduğu değerlendirmesini yaptığı görülmektedir. Bu bağlamda gazetenin haberde açılamalarına yer verdiği profesörün ifadeleri üzerinden konuyu nesnel bir tutumla ortaya koymaya çalıştığı izlenimi vermeye çalıştığı dikkat çekmektedir. Ancak aktarılan ifadelerin bir kısmında tırnak işaretinin kullanılmadığı ve bu anlamda gazetenin açıklamaları içselleştirdiği, konuyu nesnel bir tavırla ele almadığı görülmektedir. Ayrıca bir önceki gün "Barbarlık" olarak adlandırılan saldırının bu sayıda "Terör" olarak tanımlandığı dikkat çekmektedir. Ancak habere konu olan olayın geri planı hakkında herhangi bir açılamaya yer verilmediği, saldırının esas nedeni dışındaki ayrıntıların kaynak belirtilmeden aktarıldığı, Yeni Zelanda Başbakanı ve saldırıya yönelik değerlendirmelerine yer verilen profesörün durum tanımlaması üzerinden bir haber söyleminin inşa edildiği görülmektedir. $\mathrm{Bu}$ bağlamda haberde saldırıya yönelik ardalan ve bağlam bilgisi belirtilmezken, haberde profesörün ve Yeni Zelanda Başbakanı Ardern’in ifadelerinin kaynak olarak tercih edildiği dikkat çekmektedir. Haberde tercih edilen ilk görselde birbirine sarılan iki kişinin görseli ile haberin üst başlı̆̆ında vurgulanan "kenetlendi" ifadesinin retoriksel açıdan desteklendiği görülmektedir. Haberde yer alan ikinci görselde ise elleri kelepçeli bir kişi ve polisin yer aldığı bir görsel tercih edilmiştir. Görselle birlikte verilen yazıda teröristin pişmanlık duymadığı ve aşırı sağcıların selamlama işaretini yaptığı belirtilmektedir. Bu bağlamda gazetenin, haberin içeriğinde inşa etmek istediği söylemi hem bir uzmanın değerlendirmesine yer vererek hem de teröristin aşırı sağcıların işareti olduğu belirtilen işareti 
yaparken çekilen fotoğrafı vererek retoriksel açıdan güçlendirmeye çalıştığı görülmektedir. Aynı zamanda gazetenin, bu sayıda teröristin yüzünü buzlayarak verdiği ve bu bağlamda gazetenin saldırıyı gerçekleştirenin kim olduğu konusunda kesin bir bilgiye sahip olduğu görülmektedir.

20 Mart tarihli Cumhuriyet gazetesi, saldırıy bağlamından kopartarak farklı bir konu üzerinden aktarmayı tercih etmiştir. Sayfanın altında küçük bir şekilde yer alan haberde, "Yeni Zelanda'dan Erdoğan’a Video Uyarısı: İnsan Hayatını Tehlikeye Atıyor” başlığıyla okuyucuya aktarılan haberde ardalan bilgisine yer verilmezken, olayın bağlamından kopartılarak aktarıldığı görülmektedir. Gazete yayın politikası ve siyasal iktidarla olan ilişkileri çerçevesinde, yapılan bu açıklamayı bir muhalefet aracı olarak kullanmak istemiştir. Bu bağlamda gazetenin büyük bir terör saldırısını siyasal muhalefet etme açısından geri plana ittiği, Yeni Zelanda'dan gelen uyarıyı haber söyleminde ön plana çıardığı görülmektedir. Haberin içeriğinde teröristin çektiği görüntülerin seçim malzemesi olarak kullanılmaması yönünde Cumhurbaşkanı Erdoğan'a yapılan uyarıya ısrarla yer verilmiştir. Aynı zamanda, haber metninde bir parlamento görseli aktarllarak, "Yeni Zelanda Parlamentosu'nun dünkü oturumuna Kur'an okunarak başlandığı” bilgisine yer verilmiştir. Bu bağlamda gazetenin, haberin bütünlüğünü bölen bir görsel ve yazı ile haberin retoriğini zayıflattığı dikkat çekmektedir.

\section{Mikro analizi:}

Gazetenin 16 Mart tarihli sayısında konuyla ilgili yaptığı haberin sentaktik analizi sonrasında, gazetenin olayı adlandırırken "katliam" kelimesini tercih ettiği ve saldırıyı "barbarlık" olarak nitelendirdiği görülmektedir. Kısa ve net ifadelerin tercih edildiği haberde, "belirtildi”, "sarsıldı" gibi edilgen yapılı cümleler ile saldırıya ilişkin detaylar aktarılmaktadır. Saldırıy "barbarlık" olarak tanımlayan gazete, haberin metinleştirilmesinde tercih ettiği kelimelerle ve ilişkili cümlelerle haber metninde üretilmek istenen söylemi desteklemektedir. Bu bağlamda haber başlıklarında ve içeriğinde kullanılan "katliam", "kara gün”, "nefret”, "dehşet”, "barbarlık" gibi niteleyici kelime seçimleri ile haberin söylemi birbirini tamamlayıcı bir şekilde inşa edilmiştir. Aynı zamanda gazete, olayın haberleştirilmesinde net bir şekilde hedef gösteren bir dil tercih etmemekte ve olayın sorumluluğunu belli bir kesime yüklemeyerek sadece tanımlama yapmaktadır. Bu tutumun nedeni gazetenin yayın politikasının merkezinde seküler bir bakış açısının olduğu ve bu bakış açısı üzerinden haber söylemlerini inşa ettiği söylenebilir. Ayrıca gazetenin olayın aktarılmasında "kurşun yağdırdı", "dehşet saçtığı belirtildi”, "katliam yaptı" gibi ifadeler ile abartılı bir dili tercih ettiği görülmektedir.

17 Mart tarihli gazetenin mikro analizine göre, haberin metinleştirilmesinde açık ve net ifadelerin tercih edildiği, aktarım fiilleri ve edilgen yapılı cümleler üzerinden bir anlatımın oluşturulduğu gözlemlenmektedir. Bu bağlamda gazete, haber metninde kullandığı anlatım tarzı ile saldırıyı nesnel bir tavırla aktardığı izlenimi oluşturmaktadır. Haberin metinleştirilmesinde "pişmanlık belirtisi göstermeyen terörist", "cani”, "katliam" gibi tercih edilen kelimelerin, fonksiyonel olarak birbirini tamamlayan bir yapıda kullanıldığı görülmektedir. Genel olarak gazetenin hedef gösteren bir anlatım tercih etmediği, dolaylı yollardan gözlemlenmektedir. Bu bağlamda gazetenin, olay hakkında değerlendirmelerine yer verdiği ve haber kaynağı olarak kullandığı profesörün açıklamaları aracılığıyla saldırının aşırı sağcılarla bağlantılı olabileceği yönündeki açıklamaları tercih edilmiştir.

Aynı konu hakkında 20 Mart tarihli sayıda yayınlanan bir başka haberin sentaktik analizine göre, kısa ve net ifadelerin tercih edildiği bir anlatım tarzı ile olayın haberleştirildiği görülmektedir. Ancak haber metninde yer alan cümlelerin ve kelimelerin birbirini tamamlayıcı bir şekilde kullanılmadığı dikkat çekmektedir. Bu bağlamda haberin içeriğinde yer alan "dünyanın gündeminde" ifadesi çoğul bir anlamı 
barındırırken, haberin devamında sadece Yeni Zelanda'nın gündeminde olduğu belirtilmektedir. Bu kullanım haber metninin çelişkili bir anlatı yapısında inşa edilmesine neden olmuş, haber söyleminin çerçevesini daraltmıştır. Ayrıca haber metninde sık sık "uyarı geldi”, "belirlendi”, "başlandı" gibi edilgen yapılı ifadelerin hâkim olduğu bir anlatı yapısının tercih edildiği görülmektedir.

\section{Milli Gazete}

\section{Makro analizi:}

Milli Gazete, 16 Mart tarihindeki sayısında saldırıyı “2 Camiyi Basıp 49 Müslüman’ı Şehit Ettiler” başlığıyla büyük puntolarda manşetten okuyucularına duyurmuştur. "Yeni Zelanda'nın Christchurch kentinde Cuma namazı esnasında iki camiye yapılan silahlı terör saldırılarında 49 Müslüman şehit oldu” spotuyla devam eden haberde, gazetenin hem manşette hem de spotta saldırıda hayatını kaybedenleri "şehit" olarak tanımladığı dikkat çekmektedir. Aynı zamanda gazete, saldırıyı "terör saldırısı" ve saldırganları da "teröristler" olarak tanımlamayı tercih etmiştir. Bu bağlamda gazetenin olayı nesnel bir bakış açısıyla aktarmadığı, manşette ve spotta vurguladığı “49 Müslüman'ı şehit ettiler/oldular” ifadeleri üzerinden haberin söylemini inşa ettiği görülmektedir. Haberin içeriğinde bu söylem, terör saldırısını üstlenen kişinin saldırısı öncesi sosyal medya hesabı üzerinden "göçmen ve Müslüman karşıtı" manifesto yayınladığı bilgisi ile desteklenmiştir. Ayrıca saldırganlardan birinin kullandı̆̆ı tüfeğin üstünde "Türk ve Müslümanlara" karşı mücadele etmiş tarihi kişiliklerin yer aldığı ve saldırganın tüfeğine "Türk yiyici” adını verdiği bilgisinin ön plana çıkarıldığı görülmektedir. Bu bağlamda gazete, haberin manşetinde, spotunda ve içeriğinde ön plana çlkardığı bilgiler üzerinden haberin genelinde bütüncül bir söylem inşa etmiştir. Ancak haberde olayın geçmişi hakkında yeterli bilgilendirmenin yapılmadığı, herhangi bir kaynak belirtilmeden haber metninin oluşturulduğu dikkat çekmektedir. Haberin içeriğinde saldırıyı gerçekleştirenin birden fazla kişi olduğu bilgisi "4 saldırgandan birinin kullandığı tüfek", "4 teröristten birinin Avustralya vatandaşı olduğu bildirildi”, "teröristler”, "şehit ettiler", "Christchurch saldırganı" ifadeleri ile belirginleştirilirken, "Onlarca Sayfalık Nefret Manifestosu" ara başlığında saldırıyı üstlenenin "Brenton Tarrant" adlı bir kişi olduğu belirtilmekte ve aktarılan bilgi saldırıyı üstlenen kişinin görseli ile desteklenmektedir. Bu anlamda gazetenin saldırıyı gerçekleştirenin kim ya da kimler olduğu konusunda bir ikilem yaşadığı ve bütüncül bir anlatım inşa edemediği görülmektedir.

Milli Gazete, 17 Mart tarihli sayısında gazetenin en altında küçük bir şekilde "Papa’sı Böyle Olanın..." başlığıyla saldırıyı farklı bir bağlamda ele alarak okuyucularına aktarmayı tercih etmiştir. Siyah fon üstünde ve renkli yazılarda aktarılan haber başlı̆̆ının imalı bir şekilde kullanıldığı ve haberin genel çerçevesinin yapılan bu ima üzerinde inşa edildiği gözlemlenmektedir. Papa'nın bir görseli ile aktarılan haberde saldırıya yönelik herhangi bir ardalan bilgisine yer verilmezken, Papa Franciscus'un Yeni Zelanda'daki saldırıyı "anlamsız şiddet eylemleri” olarak tanımlamasına dikkat çekilmekte ve Papa'nın başka ülkelerde gerçekleştirilen saldırıları "terör saldırısı" olarak ifade ettiği vurgulanmaktadır. Bu anlamda, olayın bağlamından kopartıldığı ve "BBC 'Terör' Diyemedi, Daily Mirror Teröristi 'Melek Çocuk' Yaptı” ara başlıklarında, saldırının terör saldırısı olarak tanımlanmamasının ve teröristin küçüklük fotoğrafının melek çocuk olarak adlandırılmasının sorumlusu olarak Papa’yı hedef gösteren bir anlatımın tercih edildiği görülmektedir. Ayrıca, haberin içeriğinde saldırıda hayatını kaybedenlerin “şehit” olarak vurgulandı̆̆ı ve bu vurgunun “49 Müslüman’ın şehit olduğu katliam”, "O da şehit oldu”, "El-Harbi de dün şehit oldu" gibi ifadelerle ön plana çıarıldı̆̆ı dikkat çekmektedir. Aynı zamanda haberde ön plana çıkan anlatıdan farklı olarak tercih edilen diğer bir görselde yaralı bir insanın sedyede 
yatarken çekilen fotoğrafı verilerek bu görsel üzerinden saldırıda yaralanan bir kişinin daha şehit olduğu belirtilmektedir.

18 Mart tarihli sayıda, “Yeni Zelanda'da Şehit Olanların Sayısı 5o'ye Yükseldi...” ifadesi ile küçük bir şekilde yer alan haberde, gazete olayı bağlamından kopartarak aktarmayı tercih etmiştir. Haber, üç insanın üzüntülü bir bekleyiş içerisinde olduğunu temsil eden bir görsel ve "Dünyada Irkçı Terör Saldırıları Artıyor” başlığıyla devam etmektedir. Haberin içeriğinde, Müslümanlara karşı taciz, nefret suçu ve terör saldırılarının arttığ aktarılmaktadır. Bu bağlamda haberin içeriği ile başlığı arasında retoriksel açıdan bir uyumun olmadığı ve gazetenin yaşanan saldırı üzerinden dünyada ırkçı terör saldırılarının arttı̆̆ına yönelik çıkarımlarda bulunduğu görülmektedir.

19 Mart tarihli sayıda ise gazete, sayfanın altında yer alan küçük bir haberle yaşanan gelişmeleri “Terörist Tarrant'ın 3 Yıl Önce İsrail'e Gittiği Ortaya Çıktı” başlığıyla aktarmayı tercih etmiştir. Haberde, teröristin İsrail’i ziyarete gittiğinin ortaya çıttı̆̆ bilgisine yer verilmekte ancak bu bilgi kaynak belirtilmeden aktarılmakta ve olaya yönelik herhangi bir ardalan bilgisine yer verilmediği görülmektedir. Gazetenin 20 Mart tarihli sayısında ise saldırıdan sağ kurtulan bir kişinin "İlk Başta Havai Fişek Sandım” ifadesinin başlı̆̆a taşındığı görülmektedir. Küçük bir şekilde yer alan haberin spotunda, saldırıya yönelik özet bilgi aktarılırken, haberin devamında saldırıdan sağ kurtulan bir kişinin hissettiklerini gazete muhabirine anlattığı belirtilmektedir.

\section{Mikro analizi:}

Milli Gazete'nin 16 Mart tarihli sayısında konuyla ilgili yaptığı haberin sentaktik analizine göre; haberin metinleştirilmesinde uzun cümlelerin ve betimleyici ifadelerin tercih edildiği görülmektedir. Ayrıca haber metninde kullanılan cümle yapılarına bakıldığında; olayın "belirlendi", "bildirildi”, "görüldü" gibi edilgen yüklemlerin hâkim olduğu bir anlatım tarzı ile inşa edildiği dikkat çekmektedir. Bu bağlamda gazete, olayın haberleştirilmesinde kullandığı anlatım tarzı ile saldırıyı nesnel bir tavırla aktardığı izlenimi oluşturmaktadır. Ancak gazetenin haberin başlı̆̆ında “49 Müslüman’ı şehit ettiler” ifadesini kullanarak saldırıda hayatını kaybedenleri "şehit" olarak tanımlamayı tercih ettiği ve bu anlamda nesnel bir bakış açısına sahip olmadığı görülmektedir. Bu doğrultuda haberin başlığında, spotunda ve içeriğinde tercih edilen "49 Müslüman(1)şehit oldu/ettiler", "terör saldırısı", "teröristler” "göçmen ve Müslüman karşıtı” gibi ifadeler ile saldırının Müslümanlara yönelik bir terör saldırısı olduğunun kullanılan cümle grupları ve kelimelerle ön plana çıkarıldı̆̆ı dikkat çekmektedir. Gazetenin muhafazakâr düşünce etrafında şekillenen yayın politikasının, olayın bu şekilde aktarılmasına etki ettiği ve bu bağlamda haber söyleminin alternatif bir okumaya imkân tanımayan bir çerçevede oluşturulduğu gözlemlenmektedir. Ayrıca haberde, "2 camiyi basıp", "şehit ettiler”, "terörlerini camiye taşıdılar" gibi tercih edilen ifadelerle saldırıyı gerçekleştirenlerin birden fazla kişi olduğuna yönelik bir anlatı ön plana çıkartılırken, haberin içeriğinde yer alan bir görselde sadece tek bir kişinin fotoğrafı kullanılarak teröristin fotoğraftaki kişi olduğu belirtilmektedir. Bu anlamda haber metninde tercih edilen görsel ve kelime seçimlerinin, haberin içeriğinde ikili bir anlatımın oluşmasına neden olduğu gözlemlenmektedir.

17 Mart tarihli Milli Gazete'de yer alan haberin dili incelendiğinde, saldırının terör saldırısı olarak tanımlanmamasının sorumlusu olarak Papa'yı hedef gösteren bir anlatımın tercih edildiği görülmektedir. Haberin genel düşünsel yapısının bu çerçevede inşa edildiği, kelime ve cümle dizilişleri ile bu anlatımın tamamlandığı gözlemlenmektedir. Haberin sentantik yapısına bakıldığında, haberin metinleştirilmesinde tercih edilen cümlelerin uzun tutulduğu ve aktarım fiilleriyle bir anlatımın 

(pp. 220-251)

oluşturulduğu, vurgulanmak istenen bilgilerin siyah renk ile belirginleştirildiği dikkat çekmektedir. Ayrıca gazetenin saldırıda hayatını kaybedenleri "şehit" olarak tanımlamaya devam ettiği ve bu bağlamda bir önceki gün inşa edilen haber söylemini sürdürdüğü görülmektedir. 18 Mart tarihli sayının sentaktik incelemesine göre, haber metninin tutarsız bir anlatım tarzı ile oluşturulduğu dikkat çekmektedir. Görselle birlikte verilen yazıda, Yeni Zelanda'da şehit olanların sayısının yükseldiği belirtilirken, haberin devamında dünyada ırkçı terör saldırılarının arttı̆̆ı ifade edilmektedir. Ayrıca başlıkta dünyada ırkçı terör saldırılarının arttığı vurgulanırken, haberin içeriğinde dünyada Müslümanlara karşı terör saldırısının arttığına dikkat çekilmektedir. Bu bağlamda, gazetenin Yeni Zelanda'da gerçekleşen saldırı üzerinden dünyada Müslümanlara yönelik saldırıların artış gösterdiğine yönelik bir çıkarımda bulunduğu görülmektedir. Sonraki gün verilen haberin mikro analizine göre; haberin başlığında kullanılan "ortaya çıktı" edilgen cümle yapısının, teröristin İsrail'e gitmesinin gizli bir bilgiymiş gibi aktarılmasına neden olduğu görülmektedir. 20 Mart tarihli gazetede yer alan haberde tercih edilen dil yapısı incelendiğinde; "havai fişek" abartılı kelime seçimi ile saldırıda yaşanan anlara gönderme yapıldığı gözlemlenmektedir. Başlıkta kullanılan "saldırıdan sağ olarak kurtulan" ifadesinin haber içeriğinde tekrarlanarak ön plana çıkarıldığı ve bu tanımlamayla gazeteye konuşan kişinin saldırıya tanıklık ettiği vurgusunun yapıldığı görülmektedir. Ayrıca haberde "vahşet", "acı izler", "hissetmek" gibi kelime seçimleri ile duygusal çağrışımların ön planda olduğu bir söylemsel çerçevenin ön plana çıkarıldığı dikkat çekmektedir.

\section{Orta Doğu gazetesi}

\section{Makro analizi:}

Orta Doğu gazetesinin 16 Mart tarihli sayısında, gazetenin isminde yer alan "A" harfini siyah kurdele ile değiştirmiş olduğu ve tüm sayfayı siyah arka zeminle oluşturduğu gözlemlenmektedir. Bu anlamda gazetenin, tercih ettiği siyah arka fon ve siyah kurdele ile yasta olduğu görülmektedir. Gazete, yaşanan terör saldırısını "Aşırı Dinci Hıristiyan Terörist Katliam Yaptı" manşeti altında büyük puntolarda tam sayfa olarak okuyucularına aktarmakta ve manşette vurguyu "katliam" kelimesinin kırmızı ve daha iri puntolarla ön plana çıkartılması ile oluşturmaktadır. "Aşırı dinci Hıristiyan terörist" tanımlamasının yanında tercih edilen görselde Brenton Tarrant adlı bir kişinin yüzünün kırmızı renk ile belirginleştirilerek okuyuculara aktarıldığı ve manşette vurgulanan “Aşırı dinci Hıristiyan terörist”in görseldeki kişi olduğuna dair bir anlatının inşa edildiği görülmektedir. Ancak görseli kullanılan kişinin kesin olarak saldırıyı gerçekleştiren kişi olduğuna dair herhangi bir bilginin aktarılmadığı dikkat çekmektedir. Bu bağlamda gazetenin, saldırıyı gerçekleştiren kişi olup olmadığı noktasında net bir bilgiye sahip olmadığı gözlemlenmektedir. Aynı zamanda manşette saldırıyı gerçekleştirenin tek bir "terörist" olduğu belirtilirken; spotta, iki camiye terör saldırısının "düzenlendiği”, haberin içeriğinde de hem saldırıyı birden fazla "terörist” in hem de Brenton Tarrant adlı bir saldırganın gerçekleştirdiği ifade edilmektedir. Bu anlamda gazetenin, saldırıyı kim ya da kimlerin gerçekleştirdiğine yönelik net bir bilgiye sahip olmadı̆̆ı görülmektedir. Haberin spotunda olayın "terör saldırısı" ve hayatını kaybedenlerin "şehit" olarak tanımlandığı, yaralılar arasında "Türk"lerin olduğu bilgisinin ön plana çıkarıldığı görülmektedir. Haberin devamında ise spotta ön plana çıan bilgiler doğrultusunda haber söyleminin üretildiği ve bu bağlamda haber metninde Türkler üzerinden bir anlatımın inşa edildiği ve bu anlatımın haberin içeriğinde "Türkiye'ye açık tehdit", "70 sayfalık manifestonun Türklere bölümünde şu ifadelere yer verildi”, "ikisi Türk 48 kişi de yaralandı" gibi ifadelerle desteklendiği görülmektedir. Aynı zamanda haberde, saldırganın yayınladığı manifestoda Türkiye’ye yönelik tehdidine ve silahının üzerinde tarihte Osmanlılara karşı savaşmış olan isimlere ve "Turkofagos", "Viyana 1683" yazan ifadelere yer verilmektedir. Bu anlamda gazetenin, olayın ardalanını ve bağlam bilgisini okuyucuya 
aktarırken, Türklere yönelik ayrıntılar üzerinden bir anlatımı ön plana çıkardığı, saldırı anındaki ve sonrasında elde edilen detaylar üzerinden haberin genel söylemsel çerçevesini inşa ettiği görülmektedir. $\mathrm{Bu}$ tutumun nedeni ise gazetenin genel yayın politikasının milliyetçi düşünceden etkilenerek şekillenmiş olması ve bu yayın politikası doğrultusunda haber söylemlerinin inşa edilmesi olduğu söylenebilir. Bu bağlamda haber söyleminin alternatif bir okumaya olanak sağlamayan bir anlatım tarzı ile oluşturulduğu ve bu durumun tek yönlü bir okumanın gerçekleştirilmesine neden olduğu gözlemlenmektedir. Haberde tercih edilen görsellere bakıldığında ise manşette saldırının "katliam" olduğuna yönelik vurgunun, yerde üst üste yatan cansız bedenlerin buzlanmadan verilen görselleri ile desteklendiği görülmektedir. Bu anlamda gazetenin, saldırıya yönelik tanımlamalarını tercih ettiği görseller ile dikkat çekici hale getirdiği, okuyucuların söz konusu olayın boyutunu anlamasını kolaylaştıran bir yapıda kullandığı ve bu anlamda gazetenin metin ve görseller ile retoriksel açıdan bir uyum oluşturduğu görülmektedir. Aynı zamanda "49 şehit”, “49 kişi şehit düştü”, "İkisi Türk 48 kişide yaralı" gibi sayısal ifadeler ile haberin anlatımında ön plana çıan saldırının "katliam” olduğuna yönelik tanımlamanın güçlendirildiği dikkat çekmektedir.

17 Mart tarihli Orta Doğu gazetesinde, saldırı sonrası yaşanan gelişmeler "Ayasofya'da Sela Vakti" manşetiyle büyük puntolarda okuyuculara aktarılmıştır. Manşetin hemen yanında kırmızı fon üzerinde "Türk İslam Âlemi Ayakta" ifadesine yer veren gazete, haberin spotunda "49 Müslümanın şehit edilmesi, İslam dünyasını ayağa kaldırdı" ve "Şehitlere Ayasofya'da sela okunması ve gıyabi cenaze namazı için çağrılar yükseliyor" ifadeleri ile habere konu olan olayı bağlamından kopartarak farklı bir çerçevede okuyuculara aktarmaktadır. "3 Koldan Birden Saldırı", "İstanbul Hala Rüyalarında" ara başlıklarıyla detaylandırılan haberin içeriğinde, saldırının Türklere ve Türkiye’ye yönelik bir eylem olduğu bilgisinin ön plana çıkarıldığı, “49 Müslüman 'Ayasofya’nın minarelerini sökeceğiz' bildirisi yayınlandıktan sonra katledildi”, “Terörist Brenton Tarrant saldırıdan önce yayınladığı bildiride Türkiye’yi ve Erdoğan’ı tehdit etti, İstanbul'u hedef aldı", "Ayasofya minarelerinden kurtulacak ve Konstantinopolis tekrar Hiristiyan şehri olacak" gibi ifadeler ile Türkiye ve Türkler üzerinden bir haber söyleminin inşa edildiği görülmektedir. Bu bağlamda gazetenin saldırıyı nesnel bir tutumla okuyuculara aktarmadı̆̆ı, saldırısı sonrası elde edilen detaylar üzerinden bir değerlendirmede bulunduğu ve bu değerlendirme sonucunda saldırının asıl hedefinde Türkiye ve Türkler olduğuna yönelik bir söylem inşa ettiği görülmektedir. Bu bağlamda haberin devamında tercih edilen kaynak kullanımı da haber metninde üretilen söylemi destekler nitelikte kullanılmıştır. Gazete, Cumhurbaşkanı Erdoğan'ın açıklamalarına yer vererek, "Hedef Türkiye”, "Başaramayacaksınız", "Haçlı-Hilal Mücadelesi” ifadelerini ara başlıklara taşımıştır. Haberin içeriğinde Cumhurbaşkanı Erdoğan’ın tırnak işareti kullanılmadan aktarılan ifadeleri üzerinden saldırıyı gerçekleştirenlerin "Haçlı bozuntuları" olarak tanımlandığı ve saldırıyı gerçekleştirenlere yönelik tehditkâr bir anlatımın ön plana çıarıldığı görülmektedir. Bu doğrultuda "asla pes etmeyeceğiz”, "başaramayacaksınız", "biraz daha ileri giderseniz terbiye metotlarımız farklıdır", "terbiye etmesini biliriz" gibi ifadeler ile ön plana çıkarılan anlatım güçlendirilmiştir. Aktarılan ifadeler, haber kaynağı olarak kullanılan Cumhurbaşkanı Erdoğan'ın “Rabia işareti” yaparken bir görseli ve görsel üzerinde "Türkiye'nin yükselişi elbette Haçlı artıklarının zoruna gidecek" ifadesi ile desteklenmiştir. $\mathrm{Bu}$ doğrultuda gazete, Cumhurbaşkanı Erdoğan’ın ifadeleri üzerinden saldırıy gerçekleştirenlerin sorumlusu olarak "Haçlı artıkları-/bozuntuları"nı suçlayan bir anlatımı tercih etmiştir. Haberin genel söylemsel çerçevesine bakıldığında, gazetenin manşetten itibaren saldırıyı bağlamından kopartarak ele aldığı ve ayrıntılar üzerinden Türkiye ve Türkler arasında bir ilişki kurmaya çalıştığı gözlemlenmiştir. Bu bağlamda, haber metninde ön plana çıkarılan başlıklar ve haber kaynağı olarak kullanılan Cumhurbaşkanı Erdoğan'ın ifadeleri üzerinden üretilmek istenen haber söyleminin desteklendiği görülmektedir. 
Looking for the language and discourse practices in news texts: New Zealand terror attacks case / A. Gölcü; E. Bal; B. Karadeniz (pp. 220-251)

18 Mart tarihli Orta Doğu gazetesinde, "Son Kale Türkiye" başlığıyla aktarılan manşet haberde, Cumhurbaşkanı Erdoğan ve MHP lideri Devlet Bahçeli'nin seçim mitinginden açıklamalara yer verilmektedir. Manşette kullanılan ifade üzerinden dolaylı bir anlatımla terör saldırısının ima edildiği görülmektedir ve haberin içeriğinde Bahçeli’nin Yeni Zelanda'ya yönelik ifadeleri "Ey Haçlılar! Bekliyoruz Sizi” ara başlığıyla verilmektedir. Gazetenin, Bahçeli’nin açıklamalarını tırnak işareti kullanmadan aktararak içselleştirdiği ve "Ey Haçlılar gelin de sizi kanınızda boğalım", "sıkılan kurşunlar hepimize işaret etmiştir" gibi ifadeler üzerinden yapılan saldırıya karşı biz duygusunu oluşturmaya çalıştığı ve saldırıyı gerçekleştirenleri "Haçlılar" olarak tanımladığı görülmektedir. Haberin genel söylemsel çerçevesine bakıldığında, saldırının bağlamından kopartılarak haberleştirildiği ve 31 Mart Yerel Seçimleri çerçevesinde aktarıldı̆̆ı görülmüştür. Bu doğrultuda, saldırıya yönelik herhangi bir ardalan bilgisine yer verilmediği, haber kaynağı olarak tek bir kişinin açıklamaları üzerinden haber söyleminin inşa edildiği gözlemlenmektedir.

Gazetenin 19 Mart tarihli sayısında, “Çanakkale'de Bekliyoruz” manşeti altında büyük puntolarda verilen haberde, Cumhurbaşkanı Erdoğan’ın açıklamaları üzerinden bir anlatım oluşturulmuştur. Haber, retoriksel olarak Erdoğan'ın Türk Bayraklarının içinde yürürken çekilen bir fotoğrafı ile desteklenmiştir. Tematik olarak spot kullanılan ve ara başlıklarla devam eden haberde, Cumhurbaşkanının açıklamaları tırnak işareti kullanılmadan aktarılarak içselleştirilmiştir. Bu bağlamda gazete, Yeni Zelanda'da gerçekleştirilen saldırının Türkiye'ye yönelik bir mesaj olduğu çıkarımını Erdoğan'ın ifadeleri üzerinden yapmayı tercih etmiştir. Bu doğrultuda "Biz Buradayız, Çanakkale'deyiz", "Yazacak Tarihimiz Var" ara başlıklarıyla detaylandırılan haberde "mesajınızı aldık, niyetinizi anladık", "dedeleriniz geldi... tabutla geri döndü", "aynı niyetle geleceksiniz bekleriz" gibi ifadeler ile haber metninde ön plana çıkarılan söylemsel çerçeve desteklenmiştir. Haberin genel söylemine bakıldığında saldırının bağlamından kopartılarak tarihsel bir arka plan ile sunulduğu, geçmişte yaşananların hesaplaşmasının yeniden yapılabileceğini açıç̧a belirten ifadeler ile desteklendiği ve bu bağlamda haber metninde kullanılan "Sizi de dedeleriniz gibi uğurlayacağız", "Müslümanlara ve Türklere kalkan ellere karşı yazacak tarihimiz var" gibi ifadeler ile inşa edilen söylemin güçlendirildiği görülmektedir. Aynı sayıda verilen diğer bir haberde ise "Bu İşin Peşini Bırakmayacağız” başlığı altında Cumhurbaşkanı Yardımcısı ve Dışişleri Bakanı'nın Yeni Zelanda'ya yaptığı ziyaret ile ilgili ayrıntılara yer verilmiş olup, her ikisinin yer aldığı bir görsel kullanılarak haberin retoriği güçlendirilmiştir.

Gazetenin 20 Mart tarihli sayısında yer alan haberde, saldırıya yönelik gelişmeler "Yeni Zelanda Canisi Kont Dracula'nın İzinde” başlı̆̆ıyla sayfanın en altında küçük bir şekilde okuyuculara aktarılmıştır. Teröristin Türkiye'ye 2016 ylında geldiğinde, ziyaret ettiği kalenin tarihsel geçmişi açıklanarak, başlıkta belirtilen "Kont Dracula"nın Kazıkı Voyvoda” olarak da bilinen en büyük “Türk düşmanı” olduğu bilgisi aktarılmıştır. Bu doğrultuda gazetenin dolaylı bir anlatımla, teröristi “Kont Dracula” olarak adlandırdığı, teröristin de aynı "Kont Dracula” gibi “Türk düşmanı" olduğunu ima ettiği görülmektedir. Gazetenin, olayın ardalan ve bağlam bilgisine yer vermediği, teröristin Türkiye'ye gelmiş olduğu bilgisini tarihsel bir çerçevede ele alarak haber söylemini inşa ettiği gözlemlenmektedir. 22 Mart tarihli sayıda ise "Bu Bir Beka Meselesi” manşeti altında farklı bir haberin içerisinde MHP lideri Devlet Bahçeli'nin Yeni Zelanda'ya yönelik ifadeleri tırnak işareti kullanılmadan okuyucuya aktarılmıştır. Haberde, Bahçeli'nin "Katliam Yeni Zelanda'da işlendi, mesaj Müslüman Türk milletine verildi” ifadeleri üzerinden saldırının aslında Müslüman Türk milletine olduğuna yönelik vurgunun bu sayıda da sürdürüldüğü görülmektedir. Bu bağlamda gazetenin saldırıyı okuyuculara aktardığı ilk günden itibaren saldırının Türkleri hedef aldığı ve Türkiye’ye yönelik bir mesaj olduğu noktasında oluşturduğu söylemi devam ettirdiği gözlemlenmektedir. 


\section{Mikro analizi:}

Gazetenin 16 Mart tarihli sayısının sentaktik incelemesine göre; haberde karışık ve abartılı bir anlatının ön plana çıkarıldığı ve bu bağlamda tercih edilen cümlelerin ve kelimelerin böyle bir anlatının oluşmasına neden olduğu gözlemlenmektedir. Bu doğrultuda gazetenin, saldırıya yönelik ayrıntıları aktarırken "teröristlerin camiye girerken ateş açmaya başladıkları", "hareket eden her şeyi hedef aldığı”, "silahlarını ve şarjörlerini sıklıkla değiştirirken", "aşırı dinci Hıristiyan terörist”, "ağır silahlarla terör saldırısı düzenlendi” gibi betimleyici ifadelere başvurduğu görülmektedir. Haberin manşetinde yer alan "aşırı dinci Hıristiyan terörist" ifadesi ve hemen yanında kullanılan görsel ile saldırıyı tek bir kişinin gerçekleştirdiği anlaşılırken, ara başlıklarda tercih edilen "katil”, "saldırgan", "teröristler" gibi kelime seçimlerinin saldırıyı gerçekleştirenin kim ya da kimlerin düzenlediğine dair bütüncül bir söylemin inşa edilmesini engellediği görülmektedir. Gazetenin, saldırının ardalanında Türkleri hedef alan bir düşüncenin hâkim olduğunu ön plana çıkartan bir söylemi inşa ettiği ve bu bağlamda tercih edilen kelime ve tanımlamalarla haberin genel söyleminde ön plana çıkarılan anlatım tarzının pekiştirildiği görülmektedir. Haberin manşetinde tercih edilen "katliam" kelimesinin metin içinde yinelendiği ve olayın Türklere yönelik gerçekleştirilen bir "terör saldırısı" olarak belirginleştirildiği dikkat çekmektedir. Bu bağlamda haber başlıklarında ve içeriğinde kullanılan "katliam", "saldırgan", "katil", "terörist", "terör saldırısı" gibi kelime seçimleri ile haber söylemi birbirini destekleyen bir şekilde inşa edilmiştir. Haberde kullanılan cümlelerin yapısına bakıldığında ise "görüldü", "düzenlendi”, "biliniyor" gibi edilgen yapılı fillerin kullanımıyla bir anlatım tercih edildiği görülmektedir.

Orta Doğu gazetesinin 17 Mart tarihli sayısında konuyla ilgili yaptığı haberin sentaktik analizi sonrasında, bir önceki sayıda saldırının detayları üzerinden aktarılan ifadelerin bu sayıda haberin genel çerçevesini oluşturduğu gözlemlenmektedir. Bu bağlamda saldırı ve Türkiye, Türkler arasında kurulan bağlantılar, manşette ve başlıklarda ön plana çıkartılmış olup, haber kaynağı olarak açıklamalarına yer verilen kişilerin ifadeleri üzerinden aktarılmıştır. Haber kaynağı olarak tercih edilen kişilerin ifadeleri üzerinden inşa edilen haber metninde; Yair Netanyahu, Kati Piri ve teröristin açıklamaları aktarım fiilleriyle tırnak içerisinde verilirken, Cumhurbaşkanı Erdoğan'ın açıklamaları tırnak işareti kullanılmadan doğrudan aktarılmıştır. Bu bağlamda gazetenin, olayın haberleştirilmesinde tercih edilen haber kaynaklarının açıklamaları üzerinden haber söylemini inşa ettiği ve bu doğrultuda Cumhurbaşkanı Erdoğan'ın açıklamalarını içselleştirerek biz duygusunu ön plana çıkartan bir anlatı yapısını benimsediği görülmektedir. Bu bağlamda gazetenin olayı aktarırken nesnel bir bakış açısına sahip olmadığı, kendisini Cumhurbaşkanı Erdoğan'ın ifadeleri üzerinden "biz” olarak konumlandırdığı gözlemlenmektedir. Aynı zamanda gazetenin Cumhurbaşkanı Erdoğan’ın ifadeleri üzerinden saldırıyı tarihsel bir bağlamda ele aldığı ve bu doğrultuda saldırının asıl sorumlularını "Haçlı artıkları" olarak belirginleştirdiği görülmektedir. Bu bağlamda haber retoriğinde, terör saldırısının sorumlusu olarak "Haçlı artıkları" hedef gösterilmiştir ve bu doğrultuda Türkiye ve Türklerin yükselişinin "Haçlı artıkları”nın zoruna gideceği düşüncesi tercih edilen kelime ve cümleler ile ön plana çıkarılmıştır. Haberin metinleştirilmesinde kullanılan "3 koldan birden saldırı", "İstanbul hala rüyalarında", "Haçlı artıklarının zoruna gidecek” gibi cümle tercihleri ile haber metninde inşa edilen söylemsel çerçeve desteklenmiştir. $\mathrm{Bu}$ noktada haberde tercih edilen kelimeler ve cümleler arasında bir uyumun oluşturulduğu, genel olarak edilgen yapılı cümlelerin tercih edildiği, kısa ve net cümlelerle olayın aktarıldığı görülmektedir. Ayrıca gazete, "acıyı kalbimizde hissediyoruz", "hayatını kaybedenlerin hikâyeleri yürek burkuyor", "hayatını kaybeden terör mağdurları" gibi cümle tercihleriyle saldırının duygusal yönüne de dikkat çektiği gözlemlenmektedir. 

(pp. 220-251)

Gazetenin 18 Mart tarihli sayısında konuyla ilgili yer alan haberin sentaktik analizi sonrasında, saldırının bağlamından kopartılarak farklı bir konu üzerinden ele alındığı görülmektedir. MHP Lideri Devlet Bahçeli ve Cumhurbaşkanı Erdoğan'ın ortak gerçekleştirdikleri seçim mitingde, Bahçeli’nin Yeni Zelanda'ya yönelik açıklamaları üzerinden yapılacak seçimin bir beka meselesi olduğu vurgulanmıştır. Gazetenin, haber kaynă̆ı olarak kullandığı Devlet Bahçeli’nin açıklamalarını tırnak işareti kullanmadan aktardığı ve bu bağlamda Bahçeli’nin acıkmalarını içselleştirdiği, nesnel bir bakış açısına sahip olmadığı görülmektedir. Bu bağlamda gazete, kendini "biz" olarak konumlandırmıştır ve "Ey Haçllar bekliyoruz sizi hadi gelin de kanınızda boğalım”, "Yeni Zelanda'daki bir cani tarafından sıkılan kurşunlar hepimize isabet etmiştir" gibi cümle tercihleriyle inşa ettiği anlatı tarzını güçlendirmiştir. Ayrıca haberde, Devlet Bahçeli'nin açıklamaları üzerinden saldırının sorumlularına ve Türkiye'ye yönelik herhangi bir tehdide karşı gözdağı veren bir imanın oluşturulduğu görülmektedir. Bu bağlamda haber metninde tercih edilen cümle yapıları ve kelimeler ile haber metninde üretilmek istenen söylem desteklenmiştir. Gazetenin, haber kaynağı olarak MHP lideri Devlet Bahçeli’nin açıklamalarını içselleştirerek aktarmasındaki etken; gazetenin yayın politikası ile Bahçeli'nin milliyetçi politik söyleminin benzeşiyor olmasındandır. Bu çerçevede haber metninde üretilmek istenen düşünce, gazetenin yayın politikasıyla paralellik gösteren Bahçeli’nin açıllamaları üzerinden inşa edilmiştir.

19 Mart tarihli gazetede yer alan haberin sentaktik analizine göre, kısa ve net ifadeleri tercih eden gazetenin, Cumhurbaşkanı Erdoğan'ın Çanakkale Zaferi’nin 104. Yılı töreninde yaptığı açıklamalar üzerinden haberin genel söylemsel çerçevesini inşa ettiği görülmektedir. Bu bağlamda gazetenin, haber kaynağı olarak kullandığı Cumhurbaşkanı Erdoğan'ın açıklamalarını tırnak işareti kullanmadan aktararak içselleştirdiği, nesnel bir tutumla olayı haberleştirmediği görülmektedir. Haber metninde, Cumhurbaşkanı Erdoğan'ın Yeni Zelanda'da gerçekleştirilen saldırının Türkiye'ye yönelik mesajlar içerdiği bilgisinin ön plana çıkarıldığı ve bu bağlamda saldırıyı gerçekleştirenlere gözdağı veren bir anlatı yapısının inşa edildiği dikkat çekmektedir. Bu doğrultuda haber başlıklarında ve içeriğinde tercih edilen cümle grupları, kelimeler haberin gramatik yapısında Türkiye'yi hedef alanlara gözdağı veren bir söylemsel çerçevenin inşa edilmesini kolaylaştırmıştır. Bu bağlamda "Çanakkale'de bekliyoruz", "Biz buradayız, Çanakkale'deyiz”, "sizi de dedeleriniz gibi uğurlayacağız”, "tüm masumlara, tüm Müslümanlara ve Türklere kalkan ellere karşı yazacak tarihimiz var" gibi tercih edilen ifadelerle haber metninde üretilmek istenen söylemin desteklendiği görülmektedir. Ayrıca gazetenin, Cumhurbaşkanı Erdoğan'ın açıklamaları üzerinden kendini biz olarak konumlandırdığı ve bu doğrultuda "niyetinizi anladık", "buradayız", "bizi sınıyorlar", "gelecekseniz bekleriz" gibi tamlamalarla bunu açıkça ortaya koyduğu dikkat çekmektedir.

20 Mart tarihli sayıda yer alan haberin sentaktik analizi sonrasında, haberin konuşma dilinde "kalmış", "ziyaret etmiş" gibi ifadelerle metinleştirildiği, betimleyici ifadelerin ön planda olduğu bir anlatı yapısının benimsendiği görülmektedir. Haber metninde saldırıya yönelik çıkarımların yapıldığı ve tercih edilen kelime seçimleri ile üretilmek istenen söylemin desteklendiği gözlemlenmektedir. Bu bağlamda başlıkta teröristin “Kont Dracula'nın izinde” olduğu vurgulanırken, metin içerisinde Kont Dracula'nın en büyük Türk düşmanı olduğu belirtilmektedir. Bu noktada gazetenin kelime tercihleri ile dolaylı olarak teröristin asıl hedefinin Türkler olduğuna yönelik bir söylemi inşa ettiği görülmektedir. 22 Mart tarihli sayıda yer alan olayın haberleştirilmesinde kullanılan dil incelendiğinde, saldırıda asıl verilmek istenilen mesajın Türk milletine olduğuna yönelik bir söylemin ön plana çıarıldığı ve yapılacak seçimlerin bu bağlamda bir beka meselesi olduğunun vurgulandığı dikkat çekmektedir. Bu noktada haberde tercih edilen cümlelerin birbirini tamamlayan bir şekilde kullanıldığı görülmektedir. 


\section{Sözcü gazetesi}

\section{Makro analizi:}

Sözcü gazetesi, 16 Mart tarihli sayısında yaşanan terör saldırısını "Dünyayı Ayağa Kaldıran Saldırı" başlı̆̆ altında okuyucularına aktarmıştır. Üst başlığın hemen altında kullanılan haberin manşeti ise başlığa göre daha iri puntolarda "Alçak Katil İki Camiyi Basıp 49 Kişiyi Katletti” ifadesi ile verilmiştir. Haber spotunun ilk cümlesinde saldırıyı gerçekleştiren kişi "Müslüman düşmanı ırkçı terörist” olarak tanımlanmakta ve bu bağlamda gazetenin saldırıyı, bu tanımlama üzerinden dolaylı bir anlatımla "terör saldırısı" olarak ima ettiği görülmektedir. Bu çerçevede gazetenin yaşanan olayın "terör saldırısı" olduğuna yönelik belirgin söylem inşa etmediği, "Dünyayı ayağa kaldıran saldırı" olarak adlandırmayı tercih ettiği gözlemlenmektedir. Gazetenin, spotta aktardığı "Alçak saldırıdan 3 Türk yaralı kurtuldu" bilgisi üzerinden haberin genel söylemsel çerçevesini inşa ettiği görülmektedir. Spotun hemen altında saldırıyı gerçekleştirdiği belirtilen kişinin görseli verilmekte ve görselle birlikte aktarılan ifadelerde saldırganın 2016 yılında Türkiye’ye geldiği, saldırısı öncesi yayınladığı manifestoda Türkiye ve Türkleri tehdit ettiği bilgisinin ön plana çıkarıldığı görülmektedir. Aynı zamanda "Türkler iyi” ara başlığı altında saldırıdan sağ kurtulan Türklerin son durumu hakkında bir bilgilendirmeye yer verilmiştir. Terör saldırısına yönelik bilgileri görsellerle birlikte aktaran gazetenin, yaşanan terör saldırısının esas gerekçelerine yer vermediği, saldırı anı ve sonrasında elde edilen detaylar üzerinden olayı aktardığı görülmektedir. Bu bağlamda haberin genel söylemsel çerçevesine bakıldığında, gazetenin üretilen haber söyleminde olayın ardalanını detaylandırmadan aktardığı ve spotta Türklere yönelik ön plana çıkan bilginin haber içeriğinde sürdürülmesi ile saldırıyı bağlamından kopartarak ele aldığı gözlemlenmektedir. Gazetenin olayı bu şekilde aktarmasındaki temel etkenin gazetenin yayın politikasının ulusalcı ve seküler bir bakış açısı etrafında şekilleniyor olması ve bu doğrultuda haber söylemini alternatif bir okumaya imkân tanımayan bir çerçevede inşa etmesi olduğu ifade edilebilir. Ayrıca haberin üst başlığında, spotunda ve içeriğinde olayın "Dünyayı ayağa kaldıran bir saldırı" olduğu, "Dünyanın lanetlediği” ve "Dünyayı şoke ettiği” belirtilirken, aktarılan bu ifadeleri destekleyici herhangi bir haber kaynağının kullanılmadığı, sadece Türkiye'deki parti liderlerinin saldırıya yönelik açıklamalarının “Türkiye Lanetledi” ara başlığıyla okuyuculara aktarıldığı dikkat çekmektedir.

17 Mart tarihli Sözcü gazetesinde, saldırı sonrası yaşanan gelişmeler küçük bir haber ile okuyucuya aktarılmıştır. "Dünya Saldırıyı Lanetledi” başlığıyla aktarılan haberde, başlığın hemen altında sedyede yatan bir yaralının görseli verilmiştir. Yaralının sedyede işaret parmağı havadayken çekilen fotoğrafı "Allah birdir" işareti ile ilişkilendirilmiş olup, "alçak saldırının” simgesi haline geldiği vurgulanmıştır. Bu bağlamda gazetenin yaşanan terör saldırısını, "terör" saldırısı olarak tanımlamaktan kaçındığı ve "alçak saldırı”, "saldırı” olarak tanımlamayı sürdürdüğü görülmektedir. Aynı zamanda haber başlığında belirtilen "Dünya saldırıyı lanetledi” ifadesinin hiçbir kaynak ile desteklenmediği ve tercih edilen görsel ile uyumsuz bir anlatının oluşmasına neden olduğu dikkat çekmektedir. "Irkçı caninin Türkiye bağlantısı araştırılıyor" başlığıyla devam eden haberde, gazetenin saldırıyı gerçekleştiren kişiyi "Müslüman düşmanı terörist" olarak tanımlanmaya devam ettiği ve "Irkçı cani" tanımlamasını, teröristin ırkçı işaretler yaptığı ifade edilen bir görseli ile desteklediği görülmektedir. Haberin genel söylemsel çerçevesine bakıldığında ardalan ve bağlam bilgisinin yer almadığı, bir önceki gün inşa edilen haber söyleminin devam ettirildiği gözlemlenmektedir. 


\section{Mikro analizi:}

Sözcü gazetesinin 16 Mart tarihli sayısında saldırıyla ilgili yaptığı haberin sentaktik analizi sonrasında, haberde tercih edilen kelime ve fiiller ile haber metninde inşa edilmek istenen söylemi pekiştiren ifadelerin kullanıldığı dikkat çekmektedir. Haberdeki mikro yapıya bakıldığında, saldırıya yönelik bilgilerin kısa ve basit cümlelerle hikâye tarzında okuyuculara aktarıldı̆̆ 1 ve bu bağlamda birbiriyle bağlantılı kelime ve cümle tercihleriyle anlamsal bir bütünlüğün inşa edildiği görülmektedir. $\mathrm{Bu}$ bağlamda gazete, haberin üst başlığında, manşetinde, spotunda ve içeriğinde tercih ettiği "alçak katil", "katletti", "kana buladı", "vahşet”, "feci şekilde öldü" gibi kelimeler ve tamlamalarla metnin gramatik yapısını bütüncül bir inşa etmiştir. Ayrıca gazete olayın haberleştirilmesinde "buladı", "kurtuldu", "lanetledi”, "çekim yaptı", "tehdit etti”, "camiye girdi”, "kurşuna dizdi” gibi etken yapılı ifadelerin hâkim olduğu bir anlatı yapısını tercih etmiştir. Gazetenin dolaylı bir anlatımla olayın "terör saldırısı” olduğunu ima ettiği görülmekte ancak genel olarak "Dünyayı ayağa kaldıran saldırı" olarak tanımlamayı tercih ettiği dikkat çekmektedir. Bu bağlamda gazetenin olayın haberleştirilmesinde kullandığı kelime ve cümle kalıpları ile saldırının "terör saldırısı" olduğuna yönelik gerçeği geri plana iten bir anlatımı ön plana çıkardığı gözlemlenmektedir. Gazetenin 17 Mart tarihli sayısında yer alan haberin mikro yapısında edilgen cümle yapılarının ön planda olduğu görülmüsştür. Bu bağlamda kullanılan pasif cümle kalıpları, haber içeriğinde aktarılan bilgilerin kaynağının belirsizleşmesine neden olmuştur. Haberin gramatik yapısına bakıldığında, tercih edilen kelimelerin bir önceki gün aktarılan haberle uyum içerisinde olduğu ve bu anlamda inşa edilen söylemsel çerçevenin kullanılan görseller ile desteklendiği görülmektedir.

\section{Yeni Akit gazetesi}

\section{Makro analizi:}

Yeni Akit gazetesi 16 Mart tarihli sayısında, yaşanan terör saldırısına geniş bir yer ayırmıştır. Gazete, terör saldırısını "Yeni Zelanda'da İki Camiye Yapılan Saldırı, Münferit Değil, Organize...” üst başlığı ve "Haçlı Terörü” başlığı altında büyük puntolarda okuyucularına aktarmıştır. Aynı zamanda başlığın hemen yanında saldırıda hayatını kaybedenlerin sayısı "49 Şehit" ifadesiyle büyük puntolarda verilmiştir. Bu bağlamda haberin üst başlığında kullanılan "münferit değil, organize" ifadesi ve başlıkta tercih edilen "Haçlı Terörü" tanımlaması haber söyleminde terör saldırısının tarihsel bir arka planda ele alındığını, saldırının organize bir şekilde gerçekleştiğini belirten bir anlatımın oluşmasını sağlamıştır. $\mathrm{Bu}$ söylemsel çerçevenin ortaya çlkmasında gazetenin yayın politikasının muhafazakâr düşünce etrafında şekilleniyor olması ve bu bakış açısının da olayın haberleştirilmesinde dini faktörlerin ön plana çıkmasına neden olduğu gözlemlenmektedir. Bu bağlamda yayın politikasına uygun bir dil yapısı ve kelime tercihi ile oluşturulan başlık, üst başlık ve spot gibi bölümler bölgesel ve gramatik bir uyumun haber söyleminde amaçlandığını göstermektedir. Teorik olarak bakıldığında, haberin başlığı haberin konusunu göstermektedir. Bu doğrultuda gazete, başlık ve manşette inşa ettiği haber söylemini haberin spotunda ve devamında sürdürmüştür. Haberin spotunda tercih edilen "Batı dünyasının yıllardır ektiği nefret tohumları, dün Haçlı terörüne dönüştü”, "alçakça saldırıda 49 Müslüman şehit olurken”, "Katliamı 2 yıl öncesinden planladığ hedef alan paylaşımları, olayın organize bir şekilde planlandığını ortaya koydu” ifadeleri, haberin üst başlığında ve manşetinde aktarılan bilgilerin bütüncül bir şekilde haber metninde terör saldırısının sorumluluğunu Batı Dünyasına yükleyen bir anlatımın oluşmasını sağlamıştır. Bu anlamda gazete, saldırııı genel olarak "İslam düşmanı Batı dünyasının yıllardır ektiği nefret tohumlarının Haçlı terörüne dönüşmesi” olarak ifade etmiştir ve bu bağlamda hayatını kaybedenleri "şehit” olarak tanımlamamıştır. Haberin genel söylemine bakıldığında, haber metninde ön plana çıkan Türk-İslam düşmanlığı 
çerçevesinde olaya yönelik ardalan bilgisinin aktarıldığı görülmektedir. Aynı zamanda olayın dini bir bağlamda ele alındığı ve bunun sonucunda tarihsel bir bakış açısı üzerinden Hıristiyan-Müslüman karşıtllı̆ı çerçevesinde "Haçlı Terörü" olarak tanımlanması dikkat çekmektedir. Haberde tercih edilen görsellerde ise yaralı ve cansız bedenin yer aldığı bir görsel ve kucağında yaralı bir çocuk taşıyan kişinin gösterildiği bir görsel tercih edilmiştir. Bu bağlamda haber metninde tekrar edilmiş olan "katliam", "alçak saldırı" ifadeleri, tercih edilen görseller ile desteklenmiştir.

Yeni Akit gazetesi 17 Mart tarihli sayısında, yaşanan terör saldırısına yönelik gelişmeleri Cumhurbaşkanı Erdoğan'ın açıklamaları üzerinden okuyuculara aktarmayı tercih etmiştir. Gazete, "Erdoğan: Avrupa'daki Saldırıların da, Güneyde Teröre Verilen Desteğin de Amacı Aynı” ifadelerini tırnak işareti kullanmadan üst başlığa taşımıştır. Manşet kullanılan haberde, üst başlıkta kullanılan anlatım tarzı aynı şekilde devam ettirilerek "Haçlı’nın Hedefi Türk Milleti” manşeti, üst başlı̆ga göre daha iri puntolarda verilmiştir. Gazetenin, haberin üst başlığında ve manşetinde bir önceki gün inşa edilen "Haçlı" söylemini devam ettirdiği ve "hedefin Türk milleti” olduğu konusunda imalarını haber kaynağı olarak kullandığı Cumhurbaşkanı Erdoğan’ın ifadeleri üzerinden belirginleştirdiği görülmektedir. Tematik olarak spot kullanılan haberde, üst başlıkta verilen Cumhurbaşkanı Erdoğan'ın sözleri devam ettirilmiş olup, “teröristin Türk ve Müslüman düşmanlarını örnek aldığı", "asıl dertleri Türkiye, Türk milletidir" ifadeleri üzerinden, saldırının asıl hedefinde Türkiye ve Türk milleti olduğu yönelik vurgu tekrarlanmıştır. Böylece haberin ana konusunu belirleyen üst başlık, manşet ve spotta, gazetenin saldırıyı "Türk-İslam düşmanlığı" çerçevesinde inşa ettiği görülmektedir. Cumhurbaşkanı Erdoğan’ın halkı selamlayan görseli ile devam eden haberde, "Haçlı" söyleminin fotoğraf altı yazıda da devam ettirildiği ve Cumhurbaşkanının “...Haçlı artıklarının zoruna gidecek”, “...Haçlı bozuntularına, bizi hedef alan katillere...” ifadeleri haber söylemini destekleyen bir yapıda dizayn edilmiştir. Bu bağlamda, Cumhurbaşkanı Erdoğan'ın saldırıya yönelik açıklamaları haber kaynağı olarak kullanılarak, haberin genel söylemsel çerçevesi bu doğrultuda oluşturulduğu görülmektedir. "Dertleri Erdoğan Değil, Türkiye!", "Caninin Kafası ile Gezici Kafa Aynı” ara başlıklarda da, manşet ve spottaki gibi Cumhurbaşkanı Erdoğan'ın açıklamaları üzerinden bir anlatım oluşturulduğu ve Cumhurbaşkanının açıklamalarının bir kısmının tırnak işareti ile aktarılırken, bir kısmının tırnak işareti kullanılmadan içselleştirildiği dikkat çekmektedir. Ara başlıkların hemen yanında saldırı haberiyle ilişkisiz olarak Cumhurbaşkanı Erdoğan'ın kurdele keserken yer aldığı bir görsel kullanılarak, fotoğraf altı yazıda ise gerçekleştirilen açılış töreni hakkında bilgi aktarılmıştır. Bu bağlamda, haberin genel anlatısının bölündüğü görülmektedir. "Batı için İslam Türk demektir" yer alan bir diğer ara başlıkta, haberin en başından itibaren vurgulanan saldırının Türkiye, Türkler ve Cumhurbaşkanı Erdoğan'la ilişkisi uzman kişilerin görüşlerinin aktarılmasıyla desteklenmiştir. Böylece haberde üretilen genel söylemin inandırıcıllğı, uzmanların değerlendirmeleri üzerinden güçlendirilmiştir. Olayın haberleştirilmesinde haber kaynağı olarak kullanılan Cumhurbaşkanı Erdoğan'ın açıklamaları ve uzman görüşleri üzerinden haberin söylemsel çerçevesinin belirlendiği, saldırının asıl hedefinde Türkiye ve Türk-İslam düşmanlığının olduğu bilgisinin ön planda olduğu bir anlatının benimsendiği görülmektedir. Manşetten verilen haber dışında verilen diğer haberlerde de aynı anlatım tarzının kullanıldığı ve saldırının "terör saldırısı", saldırıyı gerçekleştirenin "Hıristiyan terörist", “terörist” olarak tanımlandığı gözlemlenmektedir.

Gazete 18 Mart tarihli sayısında, “Haçlı Batı’nın İslam Düşmanlığı Katlanarak Sürüyor” üst başlığı ve "Yak, Yık, Öldür" manşetiyle büyük puntolarda okuyuculara aktarılan haberde, Yeni Zelanda'daki terör saldırılarıyla belirginlik kazanan İslam düşmanlığının Avrupa ülkelerinin hemen hemen tamamında sistematik olarak kendini gösterdiği ve dünyada Müslümanlara karşı artan terör saldırıları belirtilmiştir. 

(pp. 220-251)

Ancak gazete herhangi bir kaynak kullanmadan oluşturduğu haberde, Yeni Zelanda'da yaşanan terör saldırısı üzerinden dünyada Müslümanlara yönelik gerçekleştirilen saldırılara yer vererek, saldırıyı bağlamından kopartarak farklı bir şekilde haberleştirmiştir.

Gazete 19 Mart tarihli sayısında, saldırıda yakınını kaybeden bir kişinin ifadesini "Yeni Zelanda'daki Saldırıda İki Yakınını Şehid Veren Suriyeli Muhammed: İslam’ın Son Kalesi Türkiye” başlığıyla büyük puntolarda okuyucuya aktarmıştır. "İslam’ın Son Kalesi Türkiye” ifadesi diğerlerine göre daha da belirgin bir şekilde yazılarak ön plana çıkartılmış olup, vurgunun "Türkiye” üzerinde yoğunlaştı̆̆ görülmektedir. Bu bağlamda gazetenin, kişinin ifadeleri üzerinden İslam’ın son kalesinin Türkiye olduğunu dolaylı olarak ima ettiği gözlenmiştir. Haberin tematik yapısına bakıldığında, spot ve ara başlıkların kullanılmadığı, aynı zamanda tek bir haber kaynağının değerlendirmesi ile haberin söylemsel çerçevesinin belirlendiği görülmüştür. Ardalan ve bağlam bilgisinin yer almadı̆̆ saldırıda yakınını kaybeden Muhammed'in "İslam'ın son kalesi Türkiye, bu işin peşini bırakmasın” ve “Cumhurbaşkanı Erdoğan'dan Allah razı olsun, Türkiye, Müslümanların son kalesidir” ifadeleri üzerinden üretilen haber söylemi desteklenmiştir. Haberin genel söylemsel çerçevesinde bakıldığında, gazetenin saldırıy "terör saldırısı", saldırıyı gerçekleştireni "terörist", "Hıristiyan terörist" ve saldırıda hayatını kaybedenleri "şehit" olarak tanımlamaya devam ettiği görülmektedir. Yeni Akit gazetesinin 22 Mart tarihli sayısında, yaşanan terör saldırısı bağlamından kopartılarak aktarılmıştır. "İslam’ı Karalayan Paylaşımlara İzin, Hıristiyan Terörüne Sansür" üst başlığı ve "Haçlı Uşağı Youtube" manşetiyle verilen haberde, saldırganın kayda aldığı görüntüleri yayınlayan Akit Tv’ye, Youtube tarafindan uygulanan sansüre yönelik tepkiye yer verildiği görülmektedir.

\section{Mikro analizi:}

Yeni Akit gazetesinin 16 Mart tarihli sayısında yer alan haber metni incelendiğinde, gazetenin olayı aktarırken hedef gösteren ve suçlayan bir dil yapısı tercih ettiği görülmüştür. Gazete, haber metninde kullanmış olduğu cümle yapıları ve kelime tercihleri ile saldırıyı tarafsız bir şekilde okuyuculara aktarmamıştır. Bu doğrultuda, haber metninde kullanılan kelime ve cümlelerin dizilişi, haber metninde üretilmek istenen söylemi destekleyen bir yapının oluşmasını kolaylaştırmıştır. Bu çerçevede gazete, haber metni içerisinde saldırının organize olarak gerçekleștirildiğini tekrarlayarak vurgulamıștır. Aynı zamanda gazete, saldırıda hayatını kaybedenleri "şehit" olarak adlandırarak ve saldırının sorumlusu olarak "Batı"yı hedef göstererek ve bu tanımlamaları yineleyerek haberde belirgin bir söylemin oluşturulmasını sağlamaktadır. Haberin genel söylemsel çerçevesi incelendiğinde cümlelerin uzun tutulmuş olduğu, abartılı ifadelerin yer aldığı, saldırıya ilişkin detayların yoğun olarak aktarım fiilleriyle aktarıldığı, tercih edilen kelime ve cümle yapıları arasında bir tutarsızlı̆̆ı olduğu ve bu doğrultuda karmaşık bir anlatının ön planda olduğu görülmüştür.

Gazetenin 17 Mart tarihli sayısında yer alan saldırıya yönelik haber metinleri incelendiğinde, gazete olayı adlandırırken kullandığı cümlelerin birçoğunda hedef gösteren bir dil yapısı tercih etmiştir. Tek bir haber kaynağın açıklamaları üzerinden oluşturulan haber metninde, aktarım fiillerinin ön planda olduğu bir anlatının oluşturulduğu gözlemlenmektedir. Bu bağlamda haberin retoriği tek taraflı bir düşünsel çerçevede inşa edilmiş olup, terör saldırısı Türkiye ve Türkler üzerinden inşa edilen bir söylemsel çerçevede aktarılmıştır. Bu doğrultuda tercih edilen cümle kalıpları, fiiller ve tanımlamalar haber metninde üretilen söylemi güçlendiren bir şekilde kullanılmıştır. Haber metninin gramatik yapısı incelendiğinde, karmaşı ve uzun cümlelerin kullanıldığı görülmektedir. Ayrıca haberde üretilen 
söylemin inandırıcılığını arttırmak için uzman görüşlerine yer verildiği ve haber retoriğinin bu şekilde güçlendirilmeye çalışıldığı gözlemlenmektedir.

Gazetenin 19 Mart tarihli sayısında yer alan haberin gramatik yapısı analiz edildiğinde; sık sık tekrarlanan kelimeler ve sıfatlar ile haber metninde üretilen söylemsel çerçevenin desteklendiği gözlemlenmiştir. Haberin gramatik tasarımında ise aktif cümle yapıları ve aktarım fiillerinin tercih edildiği, özellikle "birlik", "beraberlik”, "tek vücut", "bir olmak" gibi kavramların birbirini tamamlayan bir çerçevede kullanıldığı görülmüştür. Aynı zamanda açıklamalarına yer verilen kişinin ifadeleri üzerinden dolaylı olarak İslam'ın ve Müslümanların son kalesi Türkiye ifadesi vurgulanarak ön plana çıkartılmıştır. Gazetenin diğer sayılarında yer alan haberlerin metinleştirilmesinde kullanılan dil incelendiğinde ise abartılı bir anlatımın tercih edildiği ve olayın aktarıldığı ilk gün inşa edilen söylemin sürdürüldüğü görülmektedir.

\section{Yeni Şafak gazetesi}

\section{Makro analizi:}

Yeni Şafak gazetesi 16 Mart tarihli sayısında, yaşanan terör saldırısını "Haçlı Terörü" ve "Korktuğunuz Kadar Varız" başlıkları altında büyük puntolarda iki ayrı haber olarak tam sayfa okuyucularına aktarmayı tercih etmiştir. Gazetenin en başında yer alan "Haçlı Terörü" başlıklı haberde saldırı hakkında özet bilgilere yer verilirken, "Korktuğunuz Kadar Varız" başlıklı diğer haberde ise saldırının arka planında Türkiye'yi hedef alan bir niteliğe sahip olduğu bilgisinin ön plana çıkarıldığı bir anlatı yapısının hâkim olduğu görülmektedir. "Haçlı Terörü" başlığıyla yer alan ilk haberin spotunda, saldırıda hayatını kaybedenler "şehit" olarak tanımlanmıştır ve haberin devamında kullanılan "Batı'da yükselen Nazizm, ırkçılık, İslam ve Türk düşmanlı̆̆ı Haçlı terörünü patlattı” ifadesi üzerinden doğrudan bir anlatımla terör saldırısının sorumlusu olarak "Batı" hedef gösterilmiştir. Bu doğrultuda gazetenin, saldırııı tarihsel bir çerçevede ele alarak "Haçlı terörü" olarak tanımlamayı tercih ettiği ve bu bă̆lamda hayatını kaybedenleri "şehit" olarak adlandırdığı görülmektedir. Gazetenin saldırıyı "Haçlı Terörü" olarak tanımlamasında gazetenin genel yayın politikasının muhafazakâr düşünce temelinde şekilleniyor olmasının etkili olduğu söylenebilir. Haberde, ardalan ve bağlam bilgisinin detaylandırılmadan aktarılmış olduğu, saldırının esas gerekçelerine yer verilmediği görülmektedir. Tercih edilen görseller ile haber retoriğinin güçlendirildiği ve saldırı anında yaşananların "cani 10 dakika arayla Nur ve Lindwood camilerine saldırdı", "5 yarı-otomatik silah kullanan cani”, "herkesi tek tek hedef aldığı görülüyor" gibi betimleyici ifadelerle abartılı bir şekilde aktardığı gözlemlenmektedir. Bu bağlamda, gazetenin saldırıyı tarafsız bir tutumla değerlendirmediği, tarihsel bir çerçevede ele aldığı ve haberin metinleştirilmesinde kendi yorumunu aktardığı görülmektedir. Aynı sayıda yer alan "Korktuğunuz Kadar Varız" başlığıyla verilen bir diğer haber ise büyük puntolarda okuyuculara aktarılmıştır. Siyah arka fonun kullanıldığı haberde, tematik olarak spot kullanılmakta ve aktarılan bilgilerin altının çizilerek vurgulandığı dikkat çekmektedir. Gazete spotta, teröristin saldırı öncesi yayınladığı bildiri ve kullandığı silahlar üzerindeki semboller ile "Batı" arasında bir bağlantı kurmakta ve haber söyleminde saldırının sorumluluğunu Batı'ya yükleyen bir anlatım oluşturmaktadır. Bu bağlamda "Haçlı Terörü" başlığı altında saldırının sorumluluğunu Batı'ya yükleyen anlatımın, bu haberde net bir şekilde ifade edildiği göze çarpmaktadır. Spotun devamında teröristin saldırısı öncesi yayınladığı bildiri haber kaynağı olarak kullanılmakta ve "İstanbul'u işgal etmek ve Ayasofya'yı kiliseye dönüştürmekle tehdit ettiği” ifadelerine yer verilmektedir. Bu noktada gazetenin spotta ön plana çıkardığı bilgiyi haberin devamında detaylandırdığı ve bu kapsamda bildirinin Türklerle ilgili olan bölümünde yer alan ifadelere yer vererek haber metninde üretilmek istenen söylemi aktarllan detaylarla desteklediği görülmektedir. 
Looking for the language and discourse practices in news texts: New Zealand terror attacks case / A. Gölcü; E. Bal; B. Karadeniz (pp. 220-251)

"İstanbul'daki Camileri Yıkarız" ara başlı̆̆ıyla devam eden haberde, teröristin İstanbul'a yönelik açıklamalarına yer verilmekte; "Türklerle Savaşan İsimleri Seçti” ara başlığında ise saldırganın silahı üzerinde yazan isimler verilmiş olup, bu isimlerin Türklere ve Osmanlılara karşı savaşan, zafer kazanan ya da katliam yapan kişiler olduğu belirtilmektedir. Bu bağlamda, gazetenin haberin en başından itibaren saldırının temelde Türkiye’ye yönelik mesajlar içeren bir saldırı olduğuna yönelik ön plana çıkardığı söylemler bu başlıklar altında netlik kazanmaktadır. Aynı zamanda verilen bilgilerin silahın üzerinde isimlerin yer aldığı bir görselin kullanılması ile retoriksel açıdan desteklendiği görülmektedir. Farklı ara başlıklarla ayrıntıların aktarılmaya devam edildiği haberde, Cumhurbaşkanı Erdoğan'ın dur işareti yaparken çekilen bir görseli kullanılarak "Bu millet size müsaade etmez" açıklaması ile birlikte verilmiştir. Bu bağlamda, gazetenin Erdoğan'ın ifadelerini kaynak olarak kullandığı ve onun ifadeleri üzerinden dolaylı bir anlatımla Batı’ya karşı bir mesaj verdiği görülmektedir. Retoriksel açıdan bir uyumun oluşturulduğu yazı ve görselin devamında "En Büyük Hedef Erdoğan” başlığı iri puntolarda ve Erdoğan ismi kırmızı renk ile vurgulanarak verilmektedir. Haber metninde ise teröristin Erdoğan'a yönelik suikast çağrısı yaptığı belirtilmekte ancak bu bilginin hiçbir haber kaynak kullanılmadan aktarıldığı dikkat çekmektedir. Haberin devamında "Barbarlığa Lanet Yağdı", "Türkiye Şehitler İçin Namaza Durdu" ve "Türkiye'de Olmadığı İçin Üzüldüler!" ara başlıklarına yer veren gazetenin bu başlıklar altında saldırıyı bağlamından kopartarak ele aldığı görülmektedir.

Gazete 17 Mart tarihli sayısında, terör saldırısını "Mermileri Bitsin Diye Dua Ettik" başlığıyla iri puntolarda, siyah fon üzerinde okuyucularına aktarmıştır. Tematik olarak spot kullanılan haberde, saldırının görgü tanıklarından birinin açıklamalarına yer verilmektedir. Gazetenin haberin devamında aynı anlatım tarzını benimsediği ve kişilerin ifadeleri üzerinden haberin söylemsel çerçevesini oluşturduğu görülmektedir. Ancak haber kaynağı olarak açıklamalarına yer verilen görgü tanıkları, net bir şekilde ifade edilmeyerek "görgü tanıklarından biri”, "bir diğer görgü tanığı" gibi tanımlamalarla aktarılmıştır. Gazetenin, görgü tanıklarını haber kaynağı olarak kullandığı ve kişilerin ifadelerini tırnak işareti kullanmadan manşete ve başlıklara taşıyarak içselleştirdiği görülmektedir. Gazetenin saldırıya yönelik herhangi bir ardalan ve bağlam bilgisine yer vermediği ve kişilerin "dua ederek bekledim”, "canlı olduğunu düşündüğü herkese yeniden ateş etmeye devam ediyordu”, "ölü taklidi yaptık” gibi ifadeleri ile saldırıya yönelik duygusal çağrışımların ve abartılı ifadelerin ön planda olduğu bir haber söylemini ön plana çıkardığı görülmektedir. Aynı duygusal çağrışımların "En Küçük Şehit Üç Yaşında”, "Şehitler Anıldı", "El-Harbi de Şehit Oldu” ara başlıklarında da devam ettirildiği görülmektedir. Gazete, haber metninde üretilen söylemi şehit olduğu belirtilen bir çocuğun görseli, insanların yerlere mumlar dizerken verilen görseli ve sedyede işaret parmağı havadayken fotoğrafı çekilen yaralı bir insanın görseli ile desteklemiştir. "Katili aklama çabası" ile verilen bir diğer haberde, gazete teröristin çıkarıldığı mahkemede cinayet ile suçlanmasından ve Papa'nın terör saldırısını "anlamsız şiddet eylemi” olarak tanımlamasından yola çıkarak teröriste yönelik "uluslararası aklama operasyonu”nun başladığı belirtilmektedir. "İşte Bu Yüzden Beka Meselesi” manşetiyle okuyuculara aktarılan diğer bir haberde ise saldırı bağlamından kopartılarak ele alınmakta ve Cumhurbaşkanı Erdoğan'ın seçim mitinginde Yeni Zelanda'ya yönelik açıklamaları üzerinden haberin söylemi inşa edilmektedir. Bu noktada Erdoğan'ın ifadelerinin kaynak alındığı haberde, saldırının Türkiye'ye verilen ilk mesaj olmadığı ve bu yüzden seçimlerin bir beka meselesi olduğu vurgusu yapılmaktadır. Bu bağlamda gazetenin, saldırının Türkiye'ye verilen bir mesaj olduğu söylemini temel aldığı ve bunun üzerinden seçimlerin bir beka meselesi olduğunu vurguladığı görülmektedir. Bir önceki gün saldırganı "Nazi terörist" olarak adlandıran gazete, bu sayıda da saldırganın duruşmada yaptı̆̆ işareti "Nazi işareti” olarak tanımlamakta ve bu anlamda bir önceki gün yaptığı adlandırmayı pekiştirmektedir. 
18 Mart tarihli Yeni Şafak gazetesinde, saldırıya yönelik ilginin azaldığı ve farklı bağlamlarda ele alındığı görülmektedir. Gazete isminin hemen üstünde "Linwood Kahramanı" ve "Acılarını Paylaştılar" başlıklarıyla yer alan haberlerin ilkinde; Linwood Camisi’nde ölü sayısının artmasını engellediği belirtilen bir kişi aktarılmaktadır. Gazetenin, haberi aktarırken sanki olay anını yaşıyormuşçasına bir anlatım tarzı benimsediği görülmektedir. Bu bağlamda "önledi”, "engelledi”, "uzaklaştırdı" gibi ifadelerle haberin söylemini desteklediği gözlemlenmektedir. Aynı zamanda haberin retoriğini güçlendirmek için adı geçen kişinin fotoğrafının kullanıldı̆̆ı görülmektedir. Ayrıca başlığın hemen üstünde, başörtülü iki kadının ağlarken çekilen fotoğrafına yer verilmekte ve Nur Cami’nin taziyenin merkezi olduğu, gelenlerin çiçek koyup gözyaşı döktüğü belirtilmektedir. Ancak verilen bilgi ve görsel arasında retoriksel açıdan bir uyumun olmadığı, aktarılan bilgi ve görselin haber kaynă̆ının belirtilmediği gözlemlenmektedir. "Acılarını Paylaştılar" başlı̆ıı altında ise Cumhurbaşkanı Yardımcısı ve Dışişleri Bakanı’nın Yeni Zelanda'daki Müslümanlarla bir araya geldiği belirtilmekte ve gazetenin bu ziyareti "acılarını paylaşmak" olarak nitelendirdiği görülmektedir. Gazetede yer alan "AB'deki Irkçılar Silahlanıyor" başlıklı farklı bir haberde ise başlığın hemen yanında haberin içeriğinden bağımsız olarak "Yeni Zelanda canisi Brenton Tarrant" olarak ifade edilen kişinin fotoğrafı "Dinler Savaşına Hazırlanıyorlar" yazısı ile aktarılmaktadır. Bu bağlamda gazetenin farklı bir haberin içerisinde teröristin "rrkçı" olduğuna yönelik bir imada bulunduğu ve haberin söylemini bu bağlamda inşa ettiği görülmektedir. Aynı zamanda gazetenin "Birlikte Kazanacağız" başlıklı haberde, gazetenin MHP lideri Devlet Bahçeli’nin Yeni Zelanda’daki saldırıya yönelik ifadelerini “Ey Haçlılar Biz Buradayız” ara başlı̆̆ altında verdiği görülmektedir. Bu noktada haberin genel söylemsel çerçevesine bakıldığında, saldırıya yönelik ardalan bilgisinin yer almadı̆̆ı ve konunun farklı bağlamlarda farklı konular üzerinden ele alındığı göze çarpmaktadır.

Gazetenin 19 Mart tarihli sayısında, "Şehit Sayısı 200 Olabilirdi” başlığı altında sedyede yatan ve işaret parmağı havadayken çekilen yaralının görseli verilmiş olup, sedyedeki kişinin kendisi olduğunu belirten bir kişinin ifadeleri üzerinden haberin genel çerçevesinin belirlendiği görülmektedir. Bu bağlamda gazetenin belirtilen kişinin açılamalarını kaynak olarak kullandığı ve ifadelerini başlığa, spota ve haberin içeriğine taşıyarak bir anlatı oluşturduğu gözlemlenmektedir. Aynı sayıda yer alan "Daha Yazacak Çok Tarih Var” başlıklı haberde, Cumhurbaşkanı Erdoğan'ın Çanakkale Zaferi’nin yıl dönümünde verdiği mesajlarda, saldırıya yönelik ifadelerinin ön plana çıkartılması ile haberin genel söylemsel çerçevesinin belirlendiği görülmektedir. Bu noktada gazetenin, haberin içeriğinde ve ara başlıklarda aynı anlatım tarzını devam ettirdiği ve Erdoğan'ın ifadelerini tırnak işareti kullanmadan aktararak içselleştirdiği görülmektedir. Bu noktada, "Katliamın Arkasında Kurul Var”, "Dünyadaki Mazlumlar İçin”, "Kıyamete Kadar Buradayız” gibi ara başlıkların ön plana çıktığı gözlemlenmektedir.

21 Mart tarihli gazetede, teröristin bir görseli “Netanyahu İle Görüştü Mü?” başlığı ile aktarılmaktadır. Gazete haberde, saldırıyı bağlamından kopartarak farklı bir açıdan ele almakta ve teröristin Türkiye'den sonra İsrail'e gittiği bilgisine yer verilmektedir. Gazete, temelde haberin içeriğinde terörist ve Netanyahu arasında bir temas olup olmadığını sorgulamaktadır. Ancak bunu yaparken "Tarrant'ın kendisine benzer İslamofobik açılamalar yapan ve İstanbul'a Konstantinopol diyen" şeklinde abartılı bir ifade ile Netanyahu tanımlamakta ve bu bağlamda gazetenin nesnel bir tavır sergilemediği, yorumunu haberin diline yansıttığı görülmektedir. "Şehitler toprağa verildi” başlığıyla yer alan bir diğer haberde ise tabut taşıyan insanların görseli verilerek retoriksel açıdan haberin inandırıcılığının arttırıldığı görülmektedir. Haberin içeriğinde ise duygusal çağrışımların ön planda olduğu bir anlatımın tercih edildiği gözlenmektedir. 


\section{Mikro analizi:}

Gazetenin 16 Mart tarihli sayısında yer alan haberin dili incelendiğinde; gazetenin terör saldırısını tanımlarken "Haçlı" kelimesini tercih ettiği ve saldırının sorumluluğunu "Batı'da yükselen Nazizm, ırkçllı, İslam ve Türk düşmanlığı”na yüklediği görülmektedir. Bu bağlamda, gazete yayın politikasının haberde tercih edilen kelimeleri ve cümleleri etkilediği, bu durumun haber söyleminde saldırının sorumluluğunu belirli bir kesime yükleyen bir anlatı yapısının oluşmasına neden olduğu göze çarpmaktadır. Gazetenin "kan donduran korkunç katliam”, "Haçlı terörünü patlattı", "kurşun yağdırdı", "tek tek hedef aldığı görülüyor" gibi kelime ve cümle tercihleriyle saldırı ve saldırıya yönelik ayrıntıları abartılı bir şekilde aktardığı gözlemlenmektedir. Ayrıca gazetenin haberlerin metinleştirilmesinde genel olarak konuşma dilini tercih ettiği ve "ortaya döktü”, "zafer kazanmış olması”, "kanser gibi yayıldığını" gibi ifadeler ile saldırıyı hikâye gibi aktardığı görülmektedir. Gazetenin haber metinlerinde oluşturduğu zıtlıklar üzerinden biz ve onlar ayrımı yaptığı ve bu noktada kendini "korktuğunuz kadar varız" gibi ifadeler ile biz olarak konumlandırdığı dikkat çekmektedir. Bu noktada gazetenin kendini konumlandırdığı bizi aktarırken, "yükselen ve küresel diplomaside ağırlığı artan Türkiye", "İslam dünyasının en çok sevilen ve en etkili lideri Erdoğan” gibi tanımlamalarla ifade ettiği gözlemlenmektedir. Bu bağlamda gazetenin, saldırıyı haberleştirirken nesnel bir tutum sergilemediği ve kendi yorumunu haberin söylemine eklemlediği görülmektedir.

Gazetenin 17 Mart tarihli sayısında yer alan haberlerin sentantik analizine göre, uzun cümlelerin ve abartılı bir anlatımın tercih edildiği görülmektedir. Haberde tercih edilen aktarım fiilleri ve kelime seçimleri ile üretilmek istenen söylemin desteklendiği gözlemlenmektedir. Bu noktada gazete, saldırı anında yaşananları aktaran kişilerin ifadelerini tırnak işareti içerisinde belirterek aktarırken, saldırı sonrası yaşanan gelişmeleri "düzenledi”, "geldi”, "yaptı” gibi ifadeler ile aktarmaktadır. Bu bağlamda, gazetenin haberin genel çerçevesini bu tarz bir anlatım ile oluşturduğu görülmektedir. Aynı zamanda bir önceki gün haber metinlerinde, saldırının Türklere yönelik bir mesaj olduğu söyleminin bu sayıda devam ettirildiği görülmektedir. Bu bağlamda, "Osmanlı coğrafyasını gezdi”, "işten bu yüzden beka meselesi" gibi başlıklarda ve haber içeriğinde tercih edilen cümle yapıları ve dizilişleri ile genel söylemsel çerçevenin birbirini tamamladığı gözlemlenmektedir. 18 Mart tarihli Yeni Şafak gazetesinde yer alan haberlerin mikro analizine göre, gazetenin saldırıyı farklı bağlamlarda ele aldığı ve bu noktada haber söylemlerini inşa ettiği görülmektedir. Zaman zaman gazetenin saldırı sonrası ortaya çıkan ayrıntıları ve gelişmeleri aktarırken "gözyaşı döktü”, “önledi”, "engelledi” gibi ifadelerle o anları bire bir yaşamışçasına bir anlatım tarzı benimsediği gözlemlenmiştir. 19 Mart tarihli gazetede yer alan haberlerin sentaktik analizi sonrasında, kısa ve net ifadelerle haberlerin metinleştirildiği, kişilerin ifadeleri üzerinden bir anlatımın tercih edildiği ve bu ifadeler üzerinden haberin genel söylemsel çerçevesinin belirlendiği görülmektedir.

\section{Sonuç ve tartıșma}

Bu çalışmada, farklı siyasal tercihlere yönelik yayın yapan medya kuruluşlarının benimsemiş oldukları yayın politikalarının terör eylemlerinin haberleştirilme sürecine etkisi ortaya konulmak istenmiştir. $\mathrm{Bu}$ kapsamda yayın politikaları birbirinden farklılaşan Cumhuriyet, Milli Gazete, Orta Doğu, Sözcü, Yeni Akit ve Yeni Şafak gazeteleri ele alınmış, gazetelerin olayı haberleştirirken kullanmış oldukları dil pratikleri üzerinden bir analiz yapılmıştır. Bu analizin yapılabilmesi için gazetelerin, saldırıyı nasıl haberleştirdiği Teun van Dijk’ın Sözlem Analizi yöntemiyle ele alınarak incelenmiştir. Yöntemin dil pratiklerini makro ve mikro düzeyde ele alıyor olması nedeniyle haber analizleri de makro ve mikro başlıklar altında gerçekleştirilmiştir. 
Haberlerin incelendiği bir haftalık süre içerisinde gazetelerin saldırıyı ilk gün manşetlerinden aktardıkları dikkat çekmiştir. Altı gazetenin olaya yer verişleri aynı düzeyde gerçekleşmemiş, gazeteler olayı farklı önem sıralamalarıyla okuyuculara iletmiştir. Takip eden günlerde ise bütüncül bir şekilde gazetelerin konuya yönelik ilgisinin azaldığı ve olayın bağlamından kopartılarak küçük haberler biçiminde ele alındığı gözlemlenmiştir. Cumhuriyet gazetesinin seküler bir bakış açısı etrafında şekillenen genel yayın politikası, gazetenin olayı haberleştirirken tercih etmiş olduğu dil pratiklerine de etki etmiştir. Bu etkinin, temelinde dini öğelerin hâkim olduğu bir terör olayının haberleştirilmesinde tercih edilen kelime kahıpları ve cümlelere açıcça yansıdığı gözlemlenmiştir. Gazete haber üretim sürecinde dini literatürden kelime ve anlatıları kullanmaktan ısrarla kaçınmış, haber dilini seküler bir düzlemde inşa etmeye çalışmıştır. Bu bağlamda Cumhuriyet gazetesinin saldırganı "ırkçı ve İslam karşıtı", saldırıyı ise "barbarlık", "katliam” olarak tanımladı̆̆ı ve haberlerin genel söylemini bu çerçevede şekillendirdiği görülmüştür. Açık ve net ifadelerin kullanıldı̆̆ haber metinlerinde, pasif yapılı cümlelerin hâkim olduğu bir anlatım tarzının benimsendiği, haber söyleminin inandırıcıllğını arttırmak amacıyla uzman görüşüne ve görsellere yer verildiği de ayrıca gözlemlenmiştir. Aynı zamanda gazetenin uluslararası bir bağlamda ses getiren bir olaya oldukça duyarsız kaldığı ve yeterince önem vermediği aktarılan haberlerin genelinde görülmüştür.

Sözcü gazetesinin saldırııı haberleştirdiği ilk gün "dünyayı ayağa kaldıran saldırı" olarak okuyuculara duyurduğu, saldırganı ise "alçak katil", "Müslüman düşmanı ırkçı terörist" olarak tanımladığı görülmüştür. Saldırının esas gerekçelerinin verilmediği haberlerde, abartılı ifadelerin hâkim olduğu bir anlatım tarzıyla saldırıya yönelik ayrıntılar aktarılırken, haber dili sansasyonel bir bakış açısına göre inşa edilmiştir. Bu bağlamda, haber metinlerinde saldırının ardalanında ortaya çıan Türkler ile ilgili bilgiler üzerinden bir söylemin oluşturulduğu görülmüştür. Ulusalcı ve seküler bir yayın politikasını benimsemiş olan Sözcü gazetesinin; olayın haberleştirilmesinde dini literatürü kullanmaktan kaçınması, milli unsurları ön plana çıkarması ve uluslararası bir olayı ulusal bir bağlamda aktarmaya çalışması analizler sonucunda bulgulanmıştır. Bu çerçevede gazetenin haber metinlerinde tercih etmiş olduğu dil pratikleri, gazetenin yayın politikasını destekleyen bir şekilde gerçekleşmiştir.

Muhafazakâr ve dindar bir okuyucu kitlesine yönelik yayın yapan ve bu düşünce etrafında şekillenen bir yayın politikası benimseyen Milli Gazete'nin, olayın haberleştirilmesi sürecinde bu bakış açısını yansıttığı kullanmış olduğu dil pratikleri ve haber söylemlerinde açıç̧a görülmektedir. Bu bağlamda gazetenin ilk gün saldırıyı Türk ve Müslümanlara yönelik ayrıntılar üzerinden detaylandırdığı görülmüş, haber metinlerinde bu tip ifade ve kelimeleri ön plana çıkararak olayın haberleştirilmesi sağlanmıştır. $\mathrm{Bu}$ doğrultuda gazetenin olayı aktarırken abartılı ve betimleyici ifadeler kullandığı, haberlerde saldırıyı "silahlı terör saldırısı", "katliam" gibi ifadelerle adlandırdığı ve saldırıda hayatını kaybedenleri "şehit" olarak tanımladığı gözlemlenmiştir. Aynı zamanda gazetenin, olaya yer verdiği ilk gün saldırının Türk ve Müslümanlara yönelik gerçekleştirilen bir terör saldırısı olduğu söylemini, olayın haberleştirildiği diğer sayılarda ise saldırısı sonra elde edilen detaylar ve yaptı̆̆ı çıkarımlar üzerinden devam ettirdiği görülmüştür. $\mathrm{Bu}$ bağlamda gazetenin, dünya basınında saldırının "terör saldırısı" olarak tanımlanmamasının nedeninin "Papa"nın, anlamsız şiddet eylemleri olarak tanımlanması olduğunu haber metninde ön plana çıkardığı gözlemlenmiştir. Aynı zamanda gazetenin yaşanan terör saldırısı üzerinden dünyada Müslümanlara yönelik taciz, nefret suçu ve terör saldırılarının arttığına yönelik çıkarımlarda bulunduğu görülmüştür. Bu bağlamda gazetenin saldırıyı nesnel bir tutumla okuyuculara aktarmadığı, sahip olduğu muhafazakâr ve dindar bakış açısının haber metninde kullanılan kelime ve cümle yapılarını etkilediği görülmüştür 

(pp. 220-251)

Orta Doğu gazetesi, saldırıdan sonraki ilk iki gün olayı tam sayfa olarak haberleştirmiştir ve ismindeki harfi siyah kurdele ile değiştirerek yasta olduğunu vurgulamıştır. Gazetenin olayı aktarırken abartılı ve karışık bir dil kullandığı ve saldırıyı gerçekleştireni "aşırı dinci Hıristiyan terörist”, saldırıyı "katliam”, saldırıda hayatını kaybedenleri ise "şehit" olarak ifade ettiği gözlemlenmiştir. Aynı zamanda olayın ardalanında aktarılan bilgiler üzerinden saldırıdaki asıl hedefin Türkiye ve Türklere yönelik olduğuna dair bir söylemin inşa edildiği görülmüştür. Bu bağlamda saldırıya yönelik ortaya çıkan detaylar üzerinden tarihsel bir bağlantı kurulduğu, haber dilinde bu bağlantıyı anımsatan ifadelere ve kelime tercihlerine genişçe yer verildiği ve üretilen söylemin kurulan bağlantılar üzerinden desteklendiği gözlemlenmiştir. Milliyetçi bir yayın politikası benimsemiş olan Orta Doğu gazetesinin, olayın haberleştirilmesinde milli unsurları ön plana çıartarak Türkiye ve Türklere yönelik bir söylemsel çerçevenin inşa edilmesinde etkili olduğu sonucu elde edilmiştir. Bu doğrultuda gazetenin haberlerde kurduğu "biz" ve "onlar" zıtlığı üzerinden bir anlatımı tercih ettiği, kendisini ise "biz" olarak konumlandırdığı ve bu bağlamda nesnel bir tutumla olayı okuyuculara aktarmadığı görülmüsstür.

Yeni Akit ve Yeni Şafak gazetelerinde yer alan haberlere bakıldığında ise her iki gazetenin de saldırıyı "Haçlı Terörü" olarak tanımladığı ve bu bağlamda saldırıda hayatını kaybedenleri "şehit" olarak adlandırdıkları görülmüştür. Bu bağlamda abartılı bir dilin hâkim olduğu haber metinlerinde, tarihsel bir arka planda ele alınan saldırının sorumlusu olarak Batı dünyasını hedef gösteren bir söylemin inşa edildiği gözlemlenmiştir. Bu söylemsel çerçevenin inşa edilmesinde her iki gazetenin de muhafazakâr yayın politikasını benimsemesi ve bu doğrultuda olayın temelini bir din bağlamında ele aldıkları görülmüştür. Olayı bir din temelinde aktaran ve bu çerçevede haberlerin genel söylemsel yapısını belirginleştiren Yeni Akit ve Yeni Şafak gazeteleri, yayınlamış oldukları haberler için de bu yapıyı destekleyen kelime tercihleri ve cümle kalıplarına sık sık yer vermiştir. Her iki gazete de din ve terör ilişkisi ekseninde İslam dininin terörle ilişkilendirilmek istenmesine karşı çıkarken, gerçekleşen olayı "Haçlı terörü" olarak tanımlamayı tercih etmiştir. Bu tanımlama üzerinden inşa edilen söylemler, din ve terör ilişkisini meşrulaştıran bir bakış açısının haber dilinde oluşmasına neden olmuştur. Bu bağlamda gazetelerin olayı aktarırken tercih etmiş oldukları anlatı yapıları, karşı çıkmış oldukları din-terör ilişkisinin meşrulaşmasına zemin hazırlayan bir söylemsel çerçevenin dolaylı olarak yaygınlaşmasına neden olmuştur.

Sonuç olarak medya kuruluşlarının benimsemiş oldukları yayın politikalarının haber diline ve söylemine etkisi, yine yayın politikaları ve dil pratiklerindeki farklılıklardan dolayı değişiklik göstermektedir. Yapılan analizler sonucunda medya kuruluşlarının Yeni Zelanda'da iki camiye düzenlenen terör saldırısını haberleştirirken olayı farklı açılardan ele aldığı görülmüştür. Bu bağlamda, medya kuruluşları uluslararası düzeyde gerçekleştirilen bir terör saldırısını haberleştirirken; olayı farklı dil pratikleri, farklı bağlamlar, farklı anlatı tercihleri ve söylemsel çerçeveler üzerinden okuyuculara aktarmayı tercih etmiştir. Bu farklılığın haberde kullanılan dil ve söylemde ortaya çıktığı açıkça gözlemlenmiştir. Ele alınan gazeteleri genel olarak değerlendirildiğinde, saldırıyı aktaran haberlerin ardalan-bağlam bilgisinin yeterince detaylandırılmadığı ve olayın ilk günden sonra bağlamından kopartılarak farklı çerçevelerde ele alındığı, yayın politikalarına uygun dil yapıları ve anlatı tercihleri üzerinden olayın kurgulandığı tespit edilmiştir. Ayrıca gazetelerin haber kaynağı olarak kişilerin açıklamalarını yayın politikalarına uygun şekilde dönüştürdüğü ya da çoğu zaman içselleştirdiği görülmüştür. Bu bağlamda, gazetelerin haber söylemlerini ve haber dilini destekleyecek başlık, metin ve görseller tercih ederek bütüncül bir anlatım tarzı üzerinden olayı aktardığı gözlemlenmiştir. 


\section{Kaynakça}

Akçar, E. Y. ve Çelenay, Ö. E. (2012). “Terör ve Medya İlişkisinin 2003 Yılında İstanbul'da Meydana Gelen Saldırılar Örneğiyle İncelenmesi”, NEய̈ (Nevşehir Üniversitesi) Sosyal Bilimler Enstitüsü Dergisi, 2, s. 183-197.

Andrews, K. T. and Caren, N. (2010). "Making the News: Movement Organizations, Media Attention, and the Public Agenda", American Social Review, 75 (6), s. 841-866.

Arıboğan, D. Ü. (2007). Terör Korku Hali, İstanbul: Profil.

Avşar, Z. (2002). “Terör Haberleri ve Medya”, Polis Bilimleri Dergisi, 4 (1-2), s. 21-46.

Avşar, Z. (2017). “İnternet Çağında Medya, Terör ve Güvenlik”, TRT Akademi (Olağanüstü Dönemlerde Yayincilk), 2 (3), s. 116-132.

Aydın, F. B. (2012). "Türk Basınında Nefret Söylemi: Mavi Marmara Baskını Örneği”, I. Türkiye Lisansüstü Çalışmaları Kongresi Bildiriler Kitabı 29 Haziran-1 Temmuz 2012, Konya, s. 201-224.

Aydın, F. B. (2013). Haber Söyleminde Siyasal Etki ve İdeoloji: 2002 ve 2011 Genel Seçimlerïnin Karşılaştırılmah Analizi, (Yüksek Lisans Tezi). Selçuk Üniversitesi Sosyal Bilimler Enstitüsü, Konya.

Aydın, M. (2013). Güncel Kültürde Temel Kavramlar (II. Baskı), İstanbul: Açılım Kitap.

Cangöz, İ. (2008). "Savaş Haberlerinin Sözsüz Özneleri: Iraklı Kadınların Gazete Haberlerinde Temsili”, Uygun Adrm Medya Bir Bilinç Körleşmesi, İncilay Cangöz (Der.), Ankara: Ayraç Kitapevi.

Chomsky, N. ve Herman, E. S. (1998). Medya Halka Nasll Evet Dedirtir, İstanbul: Minerva.

Crelinsten, R. D. (2013). "Terrorism and Media: Problems, Solutions, and Counter problems", Political Communication and Persuasion, Sayl: 6, s. 311-339.

Çelik, H. ve Ekşi, H. (2008). "Söylem Analizi”, Marmara Üniversitesi Atatürk Eğitim Fakültesi Eğitim Bilimleri Dergisi, 27 (27), s. 99-117.

Çora, N. (2008). Uluslararası Terörizm ve Failleri, İstanbul: Toplumsal Dönüşüm.

Deniz, Ş. ve Özel, E. K. (2018). "Bana Okurunu Söyle, Sana Manşetini Söyleyeyim: Gazetecilerin, İçerik Hiyerarşisini ve Gündemi Belirlemede Okurun Değișen Rolüne Bakışı, Gaziantep University Journal of Social Sciences, 17 (3), s. 916-940.

Devran, Y. (2010). Haber \& Söylem \& İdeoloji, İstanbul: Başlık Yayın Grubu.

Doruk, Ö. (2013). "Disiplin Toplumu ve Haber Söylemi: Gökkuşağı Derneği’nce Yapılması Planlanan Yürüyüşün Engellenmesine İlişkin Haberlerin Çözümlenmesi”, Gümüşhane Üniversitesi İletişim Fakültesi Elektronik Dergisi, 2 (1), s. 106-132.

Doyuran, L. (2018). "Medyatik Bir Çalışma Alanı Olarak Eleştirel Söylem Çözümlemesi”, Erciyes İletişim Dergisi, 5 (4), s. 301-323.

Duruoğlu, T. (2007). "Haber Yapmada İdeoloji Etkeni: 11 Eylül Olayı Üzerine Bir İnceleme”, İletişim Kuram ve Araşttrma Dergisi, Sayı: 25 s. 1-42.

Elshimi, M. (2018). "Thinking About the Symbiotic Relationship Between the Media and Terrorism", Policy Brief, 18 (12), s. 1-7.

Ergil, D. (1991). “Terörizmin Mantığı ve Hedefi”, Ankara Üniversitesi SBF Dergisi, 46 (1), s. 171-181.

Evre, B. (2009). "Söylem Analizine Yönelik Farklı Yaklaşımlar: Bir Sınıflandırma Girişimi”, Medyada Gerçekliğin İnşası Türk Medya Söylemine Eleştirel Bir Bakış, İsmet Parlak (Ed.), Konya: Çizgi.

Fairclough, N. (2015). "Dil ve İdeoloji (B. Çoban, Çev.)”, Söylem ve İdeoloji, B. Çoban ve Z. Özarslan (Haz.), İstanbul: Su.

Gadimov, J. (2015). Herman ve Chomsky'nin Propaganda Modeli: Rıza İmalatı: Kitle Medyasının Ekonomi Politiği, İlef Dergisi, 2 (2), 215-226. 
Looking for the language and discourse practices in news texts: New Zealand terror attacks case / A. Gölcü; E. Bal; B. Karadeniz (pp. 220-251)

Girgin, Ü. H. (2017). “Türkiye'deki Canlı Bomba Saldırılarını Ulusal Gazeteler Üzerinden Okumak", Akademik Sosyal Araşttrmalar Dergisi, Yll:5, Sayı:50, s. 471-516.

Gökçe, O. ve Demiray, U. (2006). “Medya-Terör İlişkisi Ya Da İkilemi”, Terörün Görüntüleri, Görüntülerin Terörü, Gökçe O. ve Demiray U. (Ed.), Konya: Çizgi.

Gölcü, A. ve Olkun, E. O. (2018). “Terör Saldırıların Haberleştirilmesinde Gazete Yayın Politikalarının Etkisi”, Yönetim, Ekonomi, Edebiyat, İslami ve Politik Bilimler Dergisi, 3 (1), s. 164-19o.

Güngör, N. (2013). İletişim, Kuramlar ve Yaklaşımlar, Ankara: Siyasal Kitapevi.

Gürses, F. (2017). Medya \& Söylem \& Demokrasi, Ankara: Ütopya.

Hout, T. V. and Jacobs, G. (2008). "News Production Theory and Practice: Fieldwork Notes on Power, Interaction and Agency", International Pragmatics Association, 18 (1), s. 59-85.

Karaduman, M. ve Akbulutgiller, B. (2018). "İnternet Gazeteciliği ve Haber Söylemi: Reina Saldırısı Haberlerinin Çözümlemesi”, Erciyes İletişim Dergisi "akademia", 5 (3), s. 12-26.

Karaduman, M. ve Batu, M. (2011). "Televizyon Haberlerinde Terörizm Olgusunun TRT’nin Haber Söylemi Bağlamında İncelenmesi”, Selçuk Üniversitesi Sosyal Bilimler Enstitüsü Dergisi, Sayı: 25, s. 359-374.

Kazan, H. (2016). "Terör-Medya İlişkisi ve Medyada Terör Haberciliği”, Güvenlik Stratejileri Dergisi, 12 (24), s. 109-146.

Kılıç, D. (2008). "Medya Haber Öykülerini Nasıl Yapılandırmaktadır? Örnek Olay: Irak Savaşı'nın Çerçevelenmesi”, Uygun Adım Medya Bir Bilinç Körleşmesi, İncilay Cangöz (Ed.), Ankara: Ayraç Kitapevi Yayınları.

Kocaman, A. (2003). “Dilbilim Söylemi”, Söylem Üzerine, Ahmet Kocaman (Haz.), Ankara: ODTÜ.

Küçüközyiğit, U. (2014). "Haber Üretim Sürecinde 'Haber Kararı' ve Karar Aşamasında Öne Çıkan Faktörler”, (Doktora Tezi). İstanbul Üniversitesi Sosyal Bilimler Enstitüsü, İstanbul.

Martin, L. J. (2008). “The Media's Role in International Terrorism”, Terrorism: An Internal Journal, 8 (2), s. 127-146.

Melek, G. ve Toker, H. (2017). "Siddet, Demokrasi ve Terör Bağlamında Ana Akım Medyanın Analizi: 15 Temmuz Darbe Girişimi”, Erciyes İletim Dergisi “akademia”, 5 (1), s. 222-234.

Okyar, O. ve Güneş, İ. D. (2001). "PKK Sempatisini Etkileyen Faktörler: Van İli Örneği”, Terörle Mücadele Makro ve Mikro Perspektifler, Uluslararası Terörizm ve Sintrașan Suçlar Sempozyumu (UTSAS 2010) Seçilmiş Bildirileri-2, O. Başıbüyük, M. A. Sözer ve N. Altun (Der.), Ankara: Polis Akademisi.

Ongun, Ö. (2014). "Uluslararası Habercilik ve Söylem: Türkiye'deki Gazetelerin Suriye İç Savaşını Yansıtma Biçimleri”, Galatasaray Üniversitesi İletişim Dergisi, Sayı:20, s. 77-97.

Özdemir, Z. (2016). "Rehine Krizi ve Anaakım Medyanın Terör Eylemlerine Yaklaşımı”, Akademik Sosyal Araştırmalar Dergisi, Yıl:4, Sayı:23, s. 237-254.

Özüyılmaz, Ö. ve Demir, A. (2001). "İstanbul İli Örneğinde Terör Suçuna Karışan Şahısların Profili”, Terörle Mücadele Makro ve Mikro Perspektifler, Uluslararası Terörizm ve Sinıraşan Suçlar Sempozyumu (UTSAS 2010) Seçilmiş Bildirileri-2, O. Başıüyük, M. Alper Sözer ve N. Altun (Der.), Ankara: Polis Akademisi.

Poyraz, B. (2002). Haber ve Haber Programlarında İdeoloji ve Gerçeklik, Ankara: Ütopya Yayınevi.

Putra, M. D. L. (2016). "New Media and Terrorism: Role of the Social Media to Countering Cyber Terrorism and Cyber Extremism for Effective Response", Communications Studies - Faculty of Social and Political Science, Universitas Indonesia, s. 1-9.

Reese, S. D. (2007). "Journalism Research And The Hierarchy of Influences Model: A Global Perspective”, Brazilian Journalism Research, 3 (2), s. 29-42.

Rigel, N. (2000). İleti Tasarmminda Haber, İstanbul: Der. 
Schneider, W. ve Raue, P. J. (2000). Gazetecinin El Kitabı (I. Aygün, Çev.), Ankara: Konrad Adenauer Vakfi.

Sözen, E. (2014). Söylem, Belirsizlik, Mübadele, Bilgi/Güç ve Refleksivite, Ankara: Birleşik.

Şen, F. Y. ve Özuyar Gümüş, S. E. (2015). Terör ve Terörizm Üzerine, Ankara: Yarg1.

Talu, U. (2000). Dipsiz Medya, İstanbul: İletişim.

Tokgöz, O. (2003). Temel Gazetecilik, Ankara: İmge Kitapevi.

van Dijk, T. (1983). "Discourse Analysis: Its Development and Application to the Structure of News, Reprinted From Journal of Communaciton, 33 (2), s. 20-43.

van Dijk, T. (1993). "Principles of Critical Discourse Analysis", Discourse\&Society, 4 (2), s. 249-283.

van Dijk, T. (1995). "Power and the News Media", Political Communication and Action, David Paletz (Ed.), Cresskill, NJ: Hampton Press.

van Dijk, T. (1999). “Söylemin Yapıları ve İktidarın Yapıları”, Medya İktidar İdeoloji, M. Küçük (Der.), Ankara: Ark.

van Dijk, T. (2006). "Ideology and Discourse Analysis", Journal of Political Ideologies, 11 (2), s. 115-140.

van Dijk, T. (2009). "News, Discourse, and Ideology", The Hand book of Journalism Studies, Karin Wahl-Jorgensen ve Thomas Hanitzsch (Eds.), New York: Routledge.

van Dijk, T. (2015). "Critical Discourse Analysis", Hand book of Discourse Analysis, in D. Tannen, H. Hamilton, D. Schiffrin (Eds.), Chichester: WileyBlackwell.

van Dijk, T. (2015). "Söylem ve İdeoloji Çokalanlı Bir Yaklaşım (N. Ateş, Çev.)”, Söylem ve İdeoloji, B. Çoban ve Z. Özarslan (Haz.), İstanbul: Su.

Yayla, A. (1990). "Terörizm: Kavramsal Bir Çerçeve", Ankara Üniversitesi SBF Dergisi, 45 (1), s. 335385 .

Yegen,..C. (2014). "Türk Yazılı Basınının HIV/AIDS Haberlerindeki Nefret Söylemi: Posta Gazetesi Örneği”, Gümüşhane Üniversitesi İletişim Fakültesi Elektronik Dergisi, 2 (3), s. 317-349.

Yılmaz, S. H. (2013). Siyasal Nefret Söylemi ve Medya, Konya: Literatürk.

Yurdigül, Y. ve Balcı, F. (2001). “Terörle Mücadelede Manipülasyon Aracı Olarak Televizyon Haberleri”, Terörle Mücadele Makro ve Mikro Perspektifler, Uluslararası Terörizm ve Sinırașan Suçlar Sempozyumu (UTSAS 2010) Seçilmiş Bildirileri-2, O. Başıbüyük, M. A. Sözer ve N. Altun. Ankara: Polis Akademisi.

Yüksel, E. (2006). "Gerçek Yaşam, Medyadaki Gerçek ve Terör Haberciliği”, Terörün Görüntüleri, Görüntülerin Terörü, Gökçe O. ve Demiray U. (Ed.), Konya: Çizgi Kitapevi.

Wilkinson, P. (1997). "The Media and Terrorism: A reassessment”, Terrorism and Political Violence, 9 (2), s. 51-64.

\section{Gazeteler}

Cumhuriyet 16 - 23 Mart 2019 tarihli sayları

Milli Gazete 16 - 23 Mart 2019 tarihli sayıları

Orta Doğu 16 - 23 Mart 2019 tarihli sayıları

Sözcü 16 - 23 Mart 2019 tarihli sayıları

Yeni Akit 16 - 23 Mart 2019 tarihli sayları

Yeni Şafak 16 - 23 Mart 2019 tarihli sayıları 